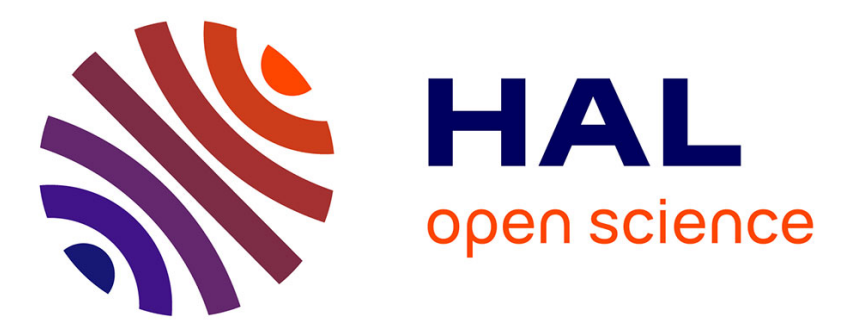

\title{
An integrated DSS for groundwater management based on remote sensing: the case of a semi-arid aquifer in Morocco
}

Maël Le Page, B. Berjamy, Y. Fakir, François Bourgin, Lionel Jarlan, A. Abourida, M. Benrhanem, Grégoire Jacob, M. Huber, F. Sghrer, et al.

\section{To cite this version:}

Maël Le Page, B. Berjamy, Y. Fakir, François Bourgin, Lionel Jarlan, et al.. An integrated DSS for groundwater management based on remote sensing: the case of a semi-arid aquifer in Morocco. Water Resources Management, 2012, 26 (11), pp.3209-3230. 10.1007/s11269-012-0068-3 . ird-00913434

\author{
HAL Id: ird-00913434 \\ https://hal.ird.fr/ird-00913434
}

Submitted on 3 Dec 2013

HAL is a multi-disciplinary open access archive for the deposit and dissemination of scientific research documents, whether they are published or not. The documents may come from teaching and research institutions in France or abroad, or from public or private research centers.
L'archive ouverte pluridisciplinaire HAL, est destinée au dépôt et à la diffusion de documents scientifiques de niveau recherche, publiés ou non, émanant des établissements d'enseignement et de recherche français ou étrangers, des laboratoires publics ou privés. 


\section{Water Resources Management \\ An integrated DSS for groundwater management based on Remote Sensing. The case of a semi-arid aquifer in Morocco \\ --Manuscript Draft--}

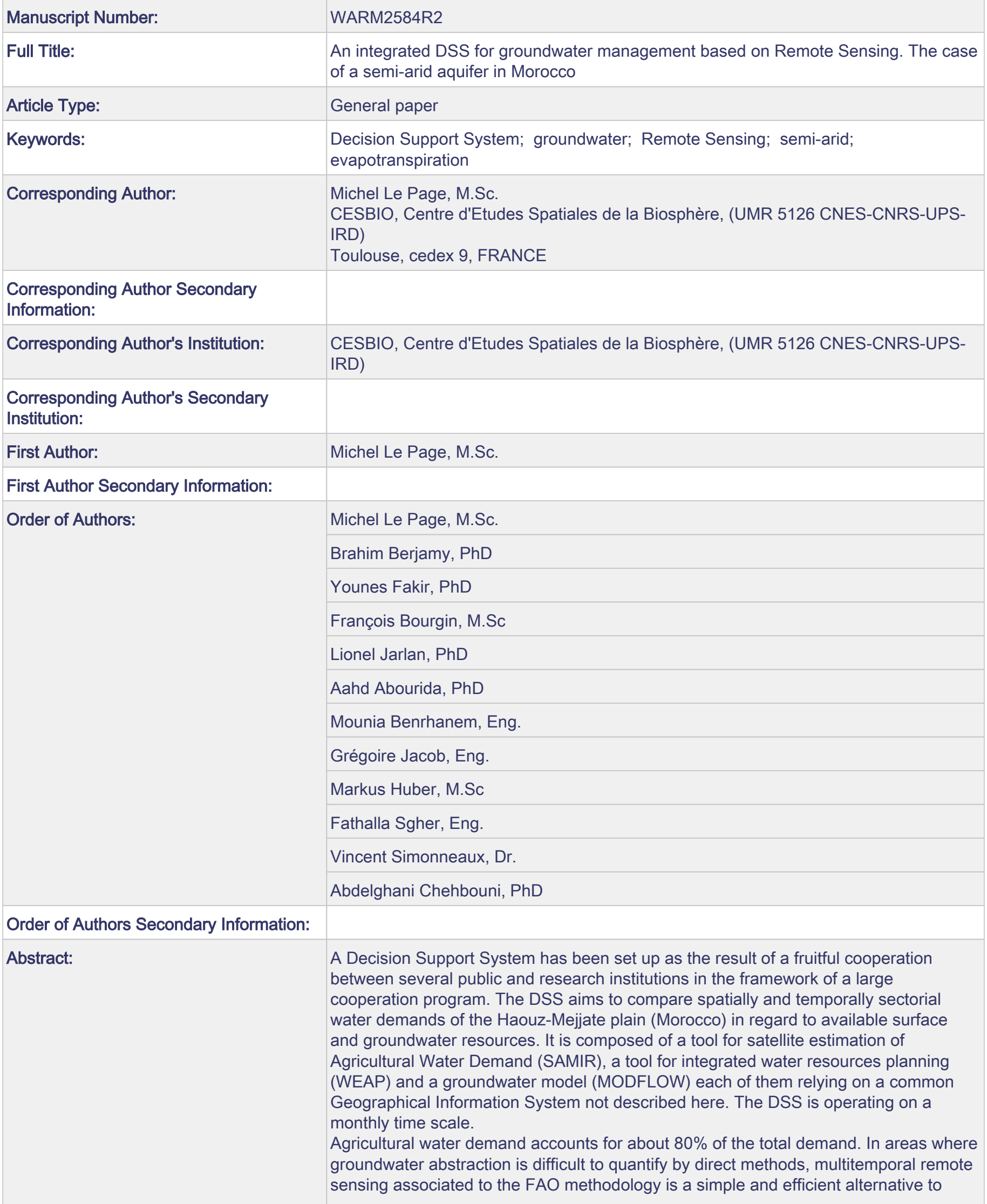


estimate Evapotranspiration (ET). In this work, a monthly estimate of ET from irrigated areas is derived from freely available MODIS NDVI for the 2001-2009 period. An important part of the paper deals with the validation of these estimates with eddy covariance flux measurements installed on different irrigated crops of the region. Results are satisfactory with a minus $6.5 \%$ error per year on the monthly time scale. This preprocessing allows to dichotomize irrigated versus non-irrigated areas, and then, to estimate groundwater abstraction in subareas distinguishing by their operating modes: traditional, dam or privately irrigated.

A dynamic linkage between MODFLOW and WEAP transfers the results of one model as input data to the other. The model restitutes both spatial and temporal variations in head charges and allows the calculation of the ground water balance. After calibration, piezometric validation is acceptable for the majority of the 21 head control points. 


\section{Comments from the Editor}

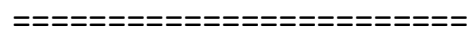

The list of references (and not bibliography) should be checked carefully (some references are not complete, some others are not written properly). Further editing is needed. The authors should make an effort to strictly follow the guide for authors of the journal (affiliation is missing etc)

The references were thoroughly revised in order to follow the journal guide, and DOI were added when available.

Authors and affiliations were added in this version. 


\title{
An integrated DSS for groundwater management based on Remote Sensing. The case of a semi-arid aquifer in Morocco
}

\author{
Le Page Michel ${ }^{1}$, Berjamy B. ${ }^{2}$, Fakir Y. ${ }^{3}$, Bourgin F. ${ }^{1}$, Jarlan L. ${ }^{1}$, Abourida A. ${ }^{3}$, \\ Benrhanem M. ${ }^{2}$, Jacob G. ${ }^{1}$, Huber M. ${ }^{4}$, Sghrer, F. ${ }^{5}$, Simonneaux V ${ }^{1}$, Chehbouni G. ${ }^{1}$ \\ (1) CESBIO (UMR 5126 CNES-CNRS-UPS-IRD), Toulouse, France \\ (2) ABHT - Agence de Bassin Hydrologique du Tensift, Marrakech, Morocco \\ (3) UCAM - Université Cadi Ayyad de Marrakech, Morocco \\ (4) BGR - Federal Institute for Geosciences and Natural Resources, Germany \\ (5) ORMVAH - Regional Office of Agriculture Enhancement of the Haouz, Morocco
}

\section{Abstract}

\begin{abstract}
A Decision Support System has been set up as the result of a fruitful cooperation between several public and research institutions in the framework of a large cooperation program. The DSS aims to compare spatially and temporally sectorial water demands of the Haouz-Mejjate plain (Morocco) in regard to available surface and groundwater resources. It is composed of a tool for satellite estimation of Agricultural Water Demand (SAMIR), a tool for integrated water resources planning (WEAP) and a groundwater model (MODFLOW) each of them relying on a common Geographical Information System not described here. The DSS is operating on a monthly time scale.
\end{abstract}

Agricultural water demand accounts for about $80 \%$ of the total demand. In areas where groundwater abstraction is difficult to quantify by direct methods, multitemporal remote sensing associated to the FAO methodology is a simple and efficient alternative to estimate Evapotranspiration (ET). In this work, a monthly estimate of ET from irrigated areas is derived from freely available MODIS NDVI for the 20012009 period. An important part of the paper deals with the validation of these estimates with eddy covariance flux measurements installed on different irrigated crops of the region. Results are satisfactory with a minus $6.5 \%$ error per year on the monthly time scale.

This preprocessing allows to dichotomize irrigated versus non-irrigated areas, and then, to estimate groundwater abstraction in subareas distinguishing by their operating modes: traditional, dam or privately irrigated.

A dynamic linkage between MODFLOW and WEAP transfers the results of one model as input data to the other. The model restitutes both spatial and temporal variations in head charges and allows the calculation of the ground water balance. After calibration, piezometric validation is acceptable for the majority of the 21 head control points. 
Keywords: Decision support system, groundwater, remote sensing, semi-arid, evapotranspiration

\section{Introduction}

Arid and semi-arid areas are characterized by their high sensitivity to climatic hazards. Their water resources can hardly meet an increasing demand driven by irrigated agriculture, population growth, improved living conditions and economic development. Global water indicators are inherently bold (Rijsberman 2006). However, projections of the widely accepted Falkenmark indicator show that by 2025, Morocco will reach other water scarce countries (Margat \& Vallée 1997, FAO 2003). The agricultural sector represents between 12 and $20 \%$ of GDP and employs about $47 \%$ of the workforce. Irrigated areas represent less than $20 \%$ of cultivated areas but contribute to nearly half of agricultural value added, three quarters of agricultural exports and provide more than a third of employment in rural areas (Belghiti 2008). As in many countries, the second part of the $\mathrm{XX}^{\text {th }}$ century witnessed a great increase in dam construction to control the water offer. Alas, severe droughts weakened the newly created water security while, simultaneously, the access to drilling and pumping was facilitated, finally driving to a hitherto unknown pressure on groundwater. The Haouz-Mejjat belongs to the Moroccan overexploited aquifers like Souss-Massa or Oum Er Bia (Bzioui 2004).

The main characteristics of the modeled area are: (1) A flat and arid plain (2) Agricultural water demand is difficult to assess; (3) Several water rights and management are superposed; (4) A well-developed hydraulic network. The setting of the model should be accessible to non-specialists, and ease the simulation of planning scenarios (McKinney 2004). By contract, several operational systems aiming to help the management of regional water resources have been developed in recent years (Feflow, Modflow, Mike-Basin), but most remain unsatisfactory due to a lack of flexibility or not dealing with the whole of the water systems including surface and groundwater abstractions.

A conceptual allocation model was preferred to hydrologic models inadequate for this flat arid and highly anthropized area. Earlier implementations of complete systems with graphical modeling tools like VENSIM or STELLA (Johannes 2004) have existed for decades, but several tools are now fully dedicated to basin modeling. A detailed comparison between MIKE BASIN, MODSIM, RIBASIM, WBaLo and WEAP may be found in (Assaf 2008), although a system like REALM (Perera 2005) could also do the work.

This previous analysis added to the existence of an already calibrated and validated yearly groundwater model for a transient state, lead to the coupled WEAP-MODFLOW package (Water Evaluation and Planning System ", www.weap21.org for details). WEAP calculates the water balance at watershed or demand sites, allocating available water resources based on the expression of demands and allocation priorities through a linear optimization procedure and has been used in several recent papers (Mutiga et al. 2010; Höllermann et al. 2010; Droubi 2008; Al-Omari et al. 2009), but without a coupled approach. The establishment of a conceptual model is facilitated by a graphical interface allowing the user to define and connect model elements in a simple and intuitive way. The tool is particularly suitable for the simulation of alternative scenarios, allowing the analysis of planning actions and management.

The model should also be implemented at the finest possible time step so that it could illustrate inadequate water use. The month was found to be the lowest common denominator among available input data. 
A major part of the study area land use is not monitored. Year to year variation of annual crops is significant, and a large extension of irrigated areas in the last decade is induced by intense development of pumping. Those facts limit the use of the classical estimation of water demand relating FAO standard Crop Coefficient trapezoids to crop surfaces (Allen et al 1998). Remote sensing is then an attractive alternative to estimate the water demand through the FAO approach. In fact, recent works have shown that ET derived from satellite imagery (ETsat) may be a valuable input to estimate net groundwater abstractions based on a simple difference (Abstraction=ETsat-Rain-Superficial Irrigation) with correction factors linked to Irrigation efficiency (Castaño et al. 2010; Mobin-ud-Din, 2005). On the land use side, highly accomplished works like the ECOCLIMAP database (Masson et al. 2003) or the CORINE land cover (European Environment Agency 2006) databases demonstrate the efficiency of the RS approach. On the Evapotranspiration side, several researches have demonstrated the legitimacy of using imagery. Among the various techniques (Courault \& Seguin 2005), the simple and easily reproducible Vegetation Index Proxy was used.

This paper is organized in four parts: the second part is dedicated to the description of the studied site, the input data and their preprocessing. In part three, model implementation and in particular groundwater abstraction estimation are described. In the fourth part, an assessment of input data and the practical implementation are revised. Finally the results are analyzed and some mitigation possibilities are explored.

\section{Water supply and demand in the Haouz Plain}

The

Haouz-Mejjate

plain

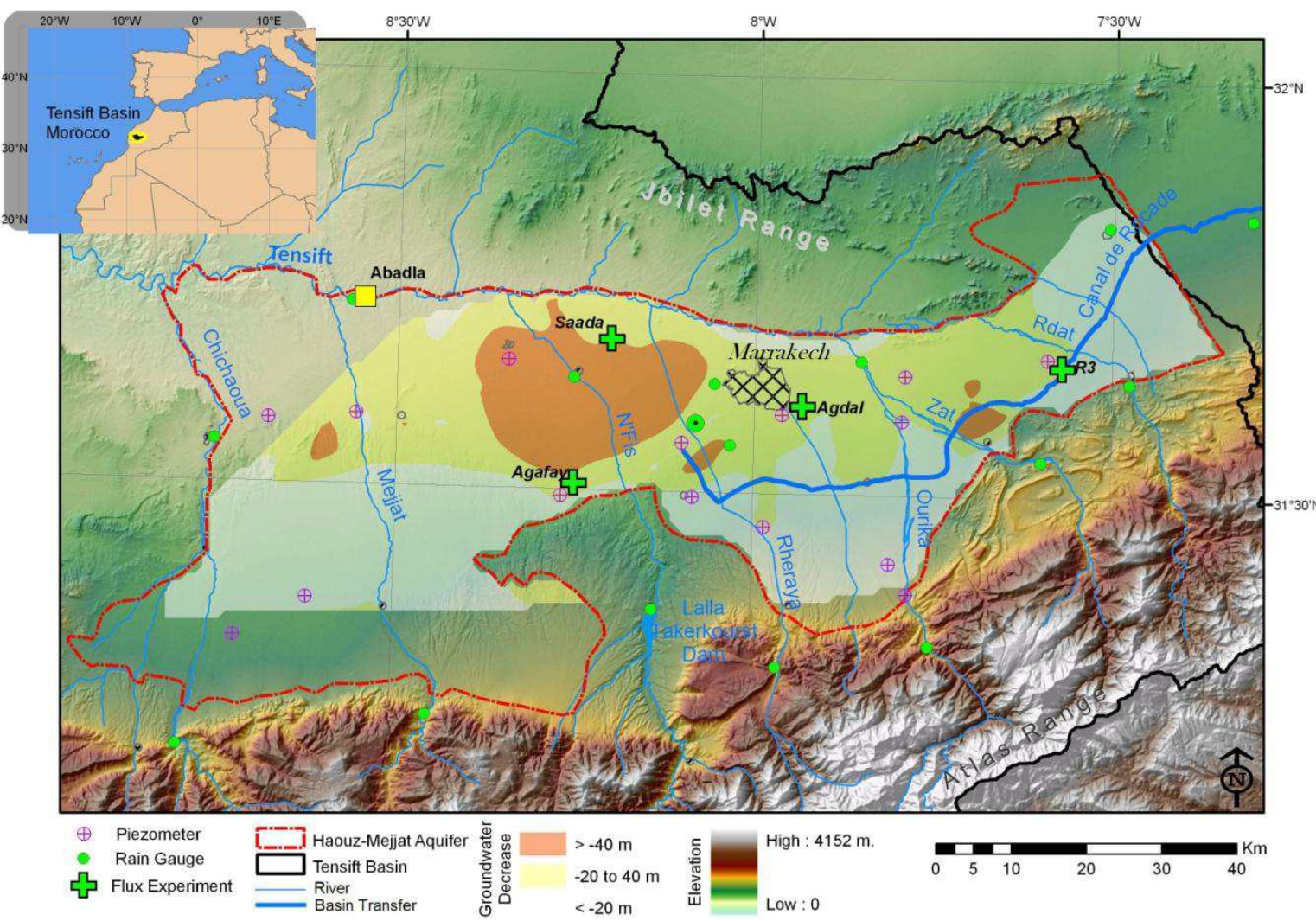

Fig 1), with an area of $6000 \mathrm{~km}^{2}$ is the most important plain in the Tensift basin. Located at $31^{\circ} 35^{\prime} \mathrm{N}, 8^{\circ} \mathrm{W}$ and between 250 and 800 m.a.s.l. the climate is semi-arid, characterized by low rainfall ( 250 mm/year) and 
high evaporative demand ( 1400mm/year). The basin includes the city of Marrakech, with about 1 million

inhabitants, receives 2 million tourists per year and contains important agricultural lands extended over 170000 ha producing mainly olives, citrus fruits and cereals.

The Haouz-Mejjate basin is part of a tectonic depression, filled by siliciclastic deposits (alluvial fans, fluviatile formations, etc.) of Neogene and Quaternary age. These sediments are brought from the HighAtlas Mountains by several rivers crossing the basin from south to north.

The great lines of water management in Morocco are well documented in (FAO 2011). Two cornerstones have considerably renewed water management in the Kingdom of Morocco. As occurring in other part of the world, the Water Law promulgated in 1995 (Law 10-95) decentralized water management into water agencies. On the other side, the Green Morocco Plan (Plan Maroc Vert) set new aggressive objectives for agriculture. In this framework, two organisms (the Basin Agency ABHT and the Agriculture Offices ORMVAH) are the main players of the game while several actors play a secondary role like operators of potable water or sanitization, public authorities, ecological organisms or institutions.

\subsection{Water Supply}

Water resources come from three inputs, namely river flows from the High Atlas Range, a Basin Water Transfer and Groundwater.

- The High-Atlas Range culminating above 4000 m.a.s.l. receives important precipitation either as rain or snow falls (Boudhar et al. 2010). The main rivers coming from the mountains cross the Haouz and Mejjat plains before reaching the Tensift River

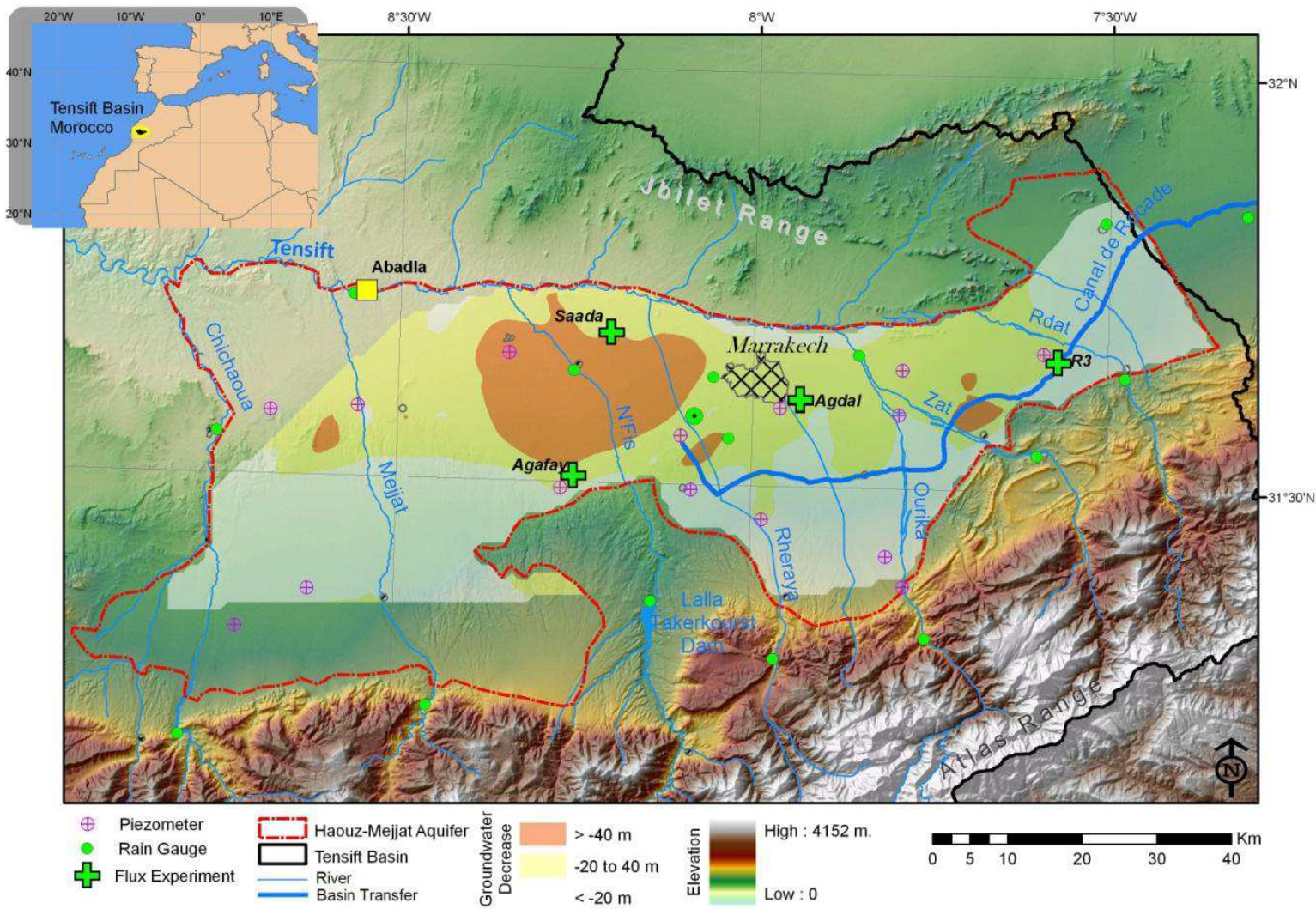

Fig 1). They play an important role in traditional irrigation at the piedmont and in the aquifer 
recharge and discharge. Two dams are installed on the N'Fis river with a total storage capacity around $13010^{6} \mathrm{~m}^{3}$.

- A water transfer is achieved by the $118 \mathrm{~km}$ long 'Canal de Rocade' with a head flow capacity of $20 \mathrm{~m} 3 / \mathrm{s}$ and an annual volume varying from $8010^{6} \mathrm{~m}^{3}$ to $22010^{6} \mathrm{~m}^{3}$ depending on the dam storage. Conceived in the late 70s (Kabbaj et al 1979) the canal has been in use since 1985 in order to secure the water supply for the city of Marrakech and to modernize irrigation areas. Improvements such as remote and automatic regulation of the canal have been carried out gradually.

- The groundwater is provided by the unconfined aquifer of the Haouz-Mejjate. The later is heterogeneous because of the variability of the alluvial deposits. The aquifer thickness varies from $20 \mathrm{~m}$ at the north margin of the plain and in many overexploited sectors in the centre of the plain, to $120 \mathrm{~m}$ at the southern part where the bottom of the aquifer is deeper and the effects of abstraction are less significant. The groundwater is presently exploited by more than 24000 pumping wells (inventory carried out between 2003 and 2006), drawing around $40010^{6} \mathrm{~m}^{3} /$ year. Consequently, during dry periods, the groundwater surface drops at an average rate of 1 to 3 $\mathrm{m} /$ year in the most areas (

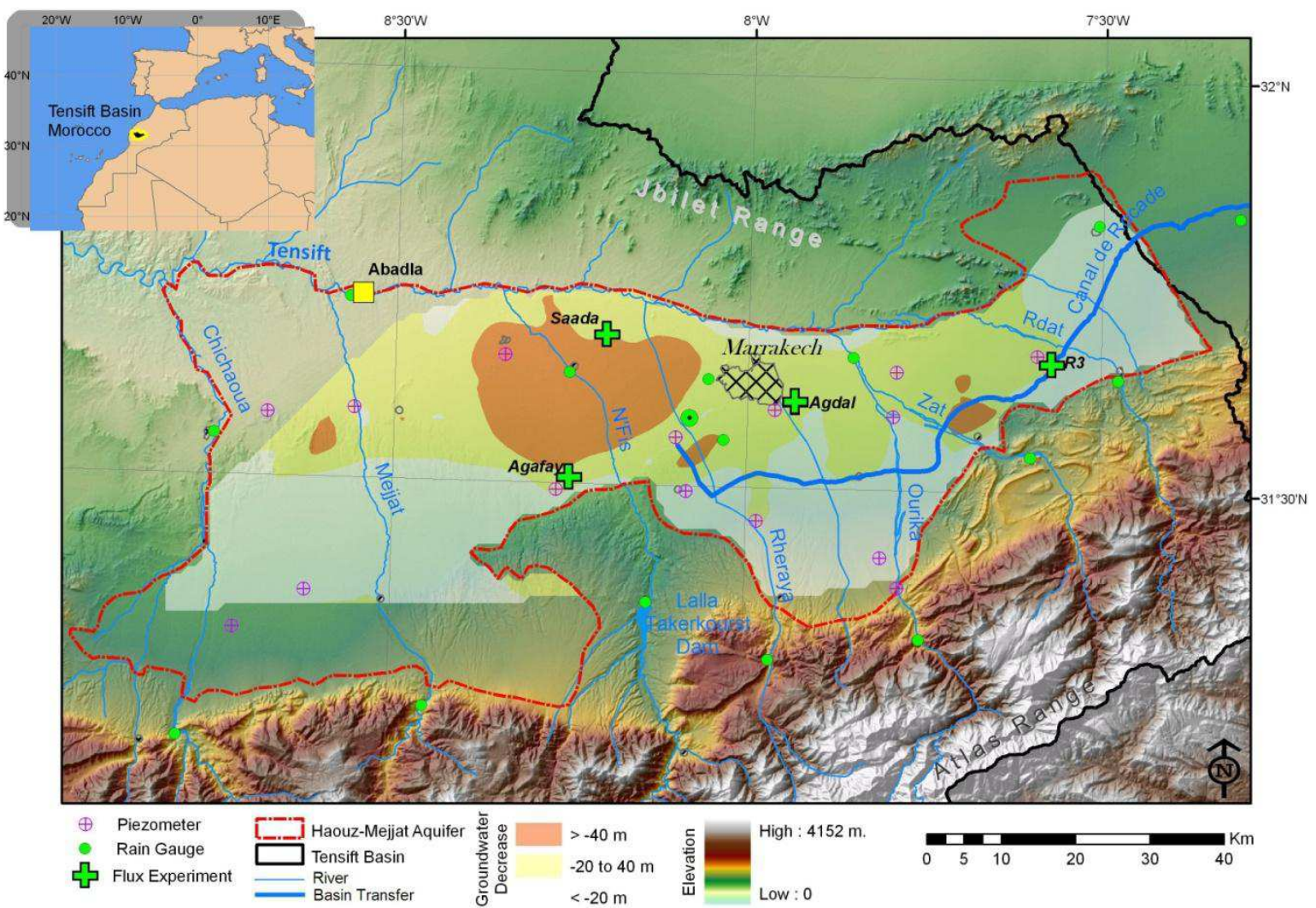

Fig 1). 


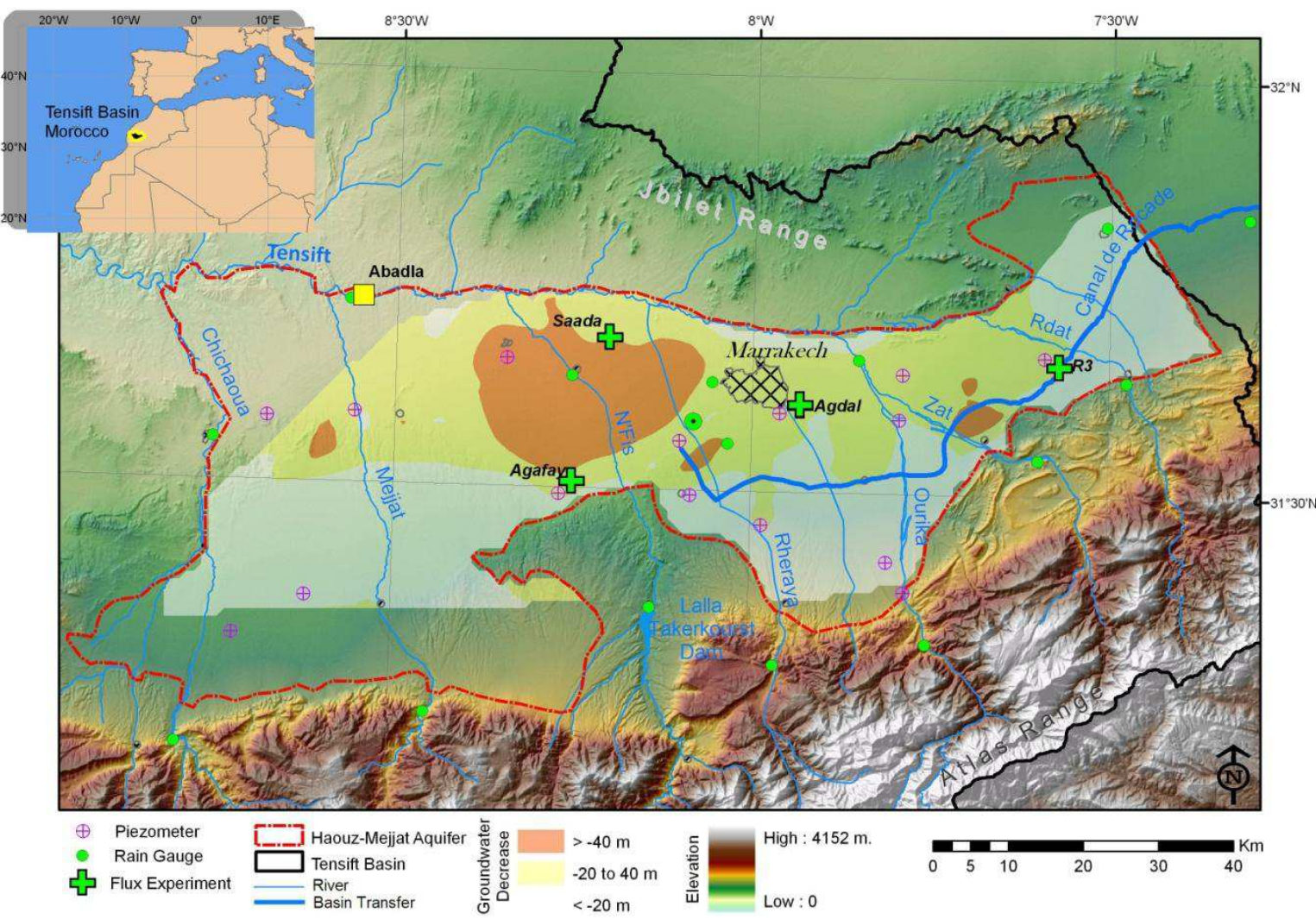

Fig 1: The Haouz plain. Piezometer, rain gauge and tower fluxes (see text) are superimposed together with a map showing the groundwater decrease between 1972 and 2008 calculated from piezometic levels.

\subsection{Water demand}

Consumptive water demand is controlled by urban potable water and agricultural demand for irrigation; industry being almost inexistent in the area.

The city of Marrakech has experienced an important population growth since the 80s (Debbi, 2004) associated with the rise of mass tourism, increase in living standards and tourist infrastructures, such as the dozen golf courses surrounding the city. By 2010, the 1 million inhabitants require around $4010^{6} \mathrm{~m}^{3}$ per year. It is expected to reach $6510^{6} \mathrm{~m}^{3}$ in the next 20 years (Projections of the National Office of Potable Water). 700.000 inhabitants are also scattered in villages and small towns around the area, a third of which is supplied by the National Office of Potable Water.

Because of the entanglement of water resources, multiplication of irrigation techniques and different levels in farmer's capitalization, irrigated agriculture is complex in the area. Also severely overlapped in the N'Fis area, four main classes may be discerned looking at water use and supply that will be called hereafter: Traditional Irrigation, Modern Irrigation, Private Irrigation, Non irrigated.

- Traditional Irrigation is composed of areas located at the piedmont of the Atlas Range fed by uncontrolled river flows. A centuries-old irrigation system called 'seguias' consisting of a complex network of small canals ( $<2 \mathrm{~m}$ wide) deviate the main flows into irrigated areas. The traditional distribution gave way to a regulated distribution during the Protectorate (late 1930s), still in use today. In case of flows exceeding the regulation algorithm, unregulated deviations may occur 
along the river, as peasants implement new 'seguias' on the fly. The irrigable area dominated by the seguia system is well defined by their spilling basins, representing an area of 151770 ha.

- Modern Irrigation matches the areas where water supply is ensured by dams. They are located along the Canal de Rocade and in the N'Fis area covering a total area of 50000 ha. The water delivered to upstream Canal de Rocade is distributed by a concrete gravity network into the different sectors. The N'Fis area is a system within itself. It associates water supply from the Canal de Rocade and the Lalla Takerkourst dam, it conserves ancient 'seguia' rights and heavily relies on groundwater. In N'Fis, surface water is also supplied under pressure or through a gravity network.

- Private Irrigation is the name given to all other irrigated areas where no surface resource exists. Those areas only rely on groundwater, and represent the higher pressure for the aquifer.

- Other areas do not rely on either superficial or subterranean water. Rainfed agriculture, principally cereals for self-consumption, is used when the rain season is propitious.

\section{Input data description and preprocessing}

\subsection{Meteorological data and evapotranspiration observations}

Although slight differences may appear between weather stations

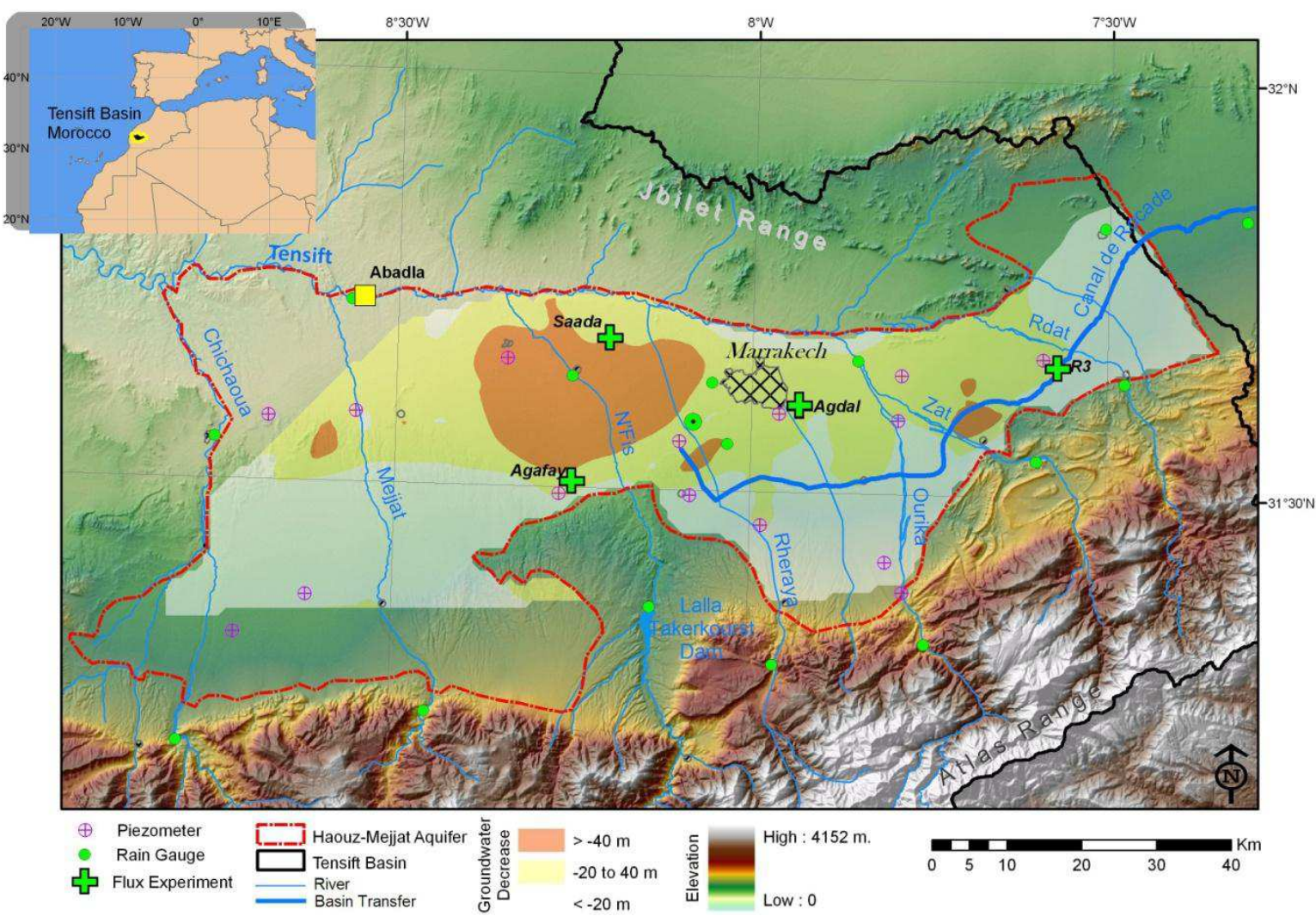

Fig 1), they are all equipped to measure air temperature, relative humidity, wind speed and direction and incoming solar radiation on a reference grass field as specified by (Allen et al., 1998). Measurements are acquired at a $30 \mathrm{~min}$ or 1 hour rate depending on the station. 
Calculation of ET0 is then achieved on a daily basis following the Penmann-Monteith equation of reference evapotranspiration ET0 (Allen et al., 1998). The coverage of agrometeorological stations evolved in time and ET0 measurements are not always available or not always representative. In order to spatialize ET0 on a daily time step, an interpolation technique relies on a reference plate. The plate is a 10 day mean ET0 calculated by the ALADIN weather forecast model for the year 2002, kindly provided by the Direction de la Météorologie Nationale.

In addition, 14 manual rain gauges with daily measurements

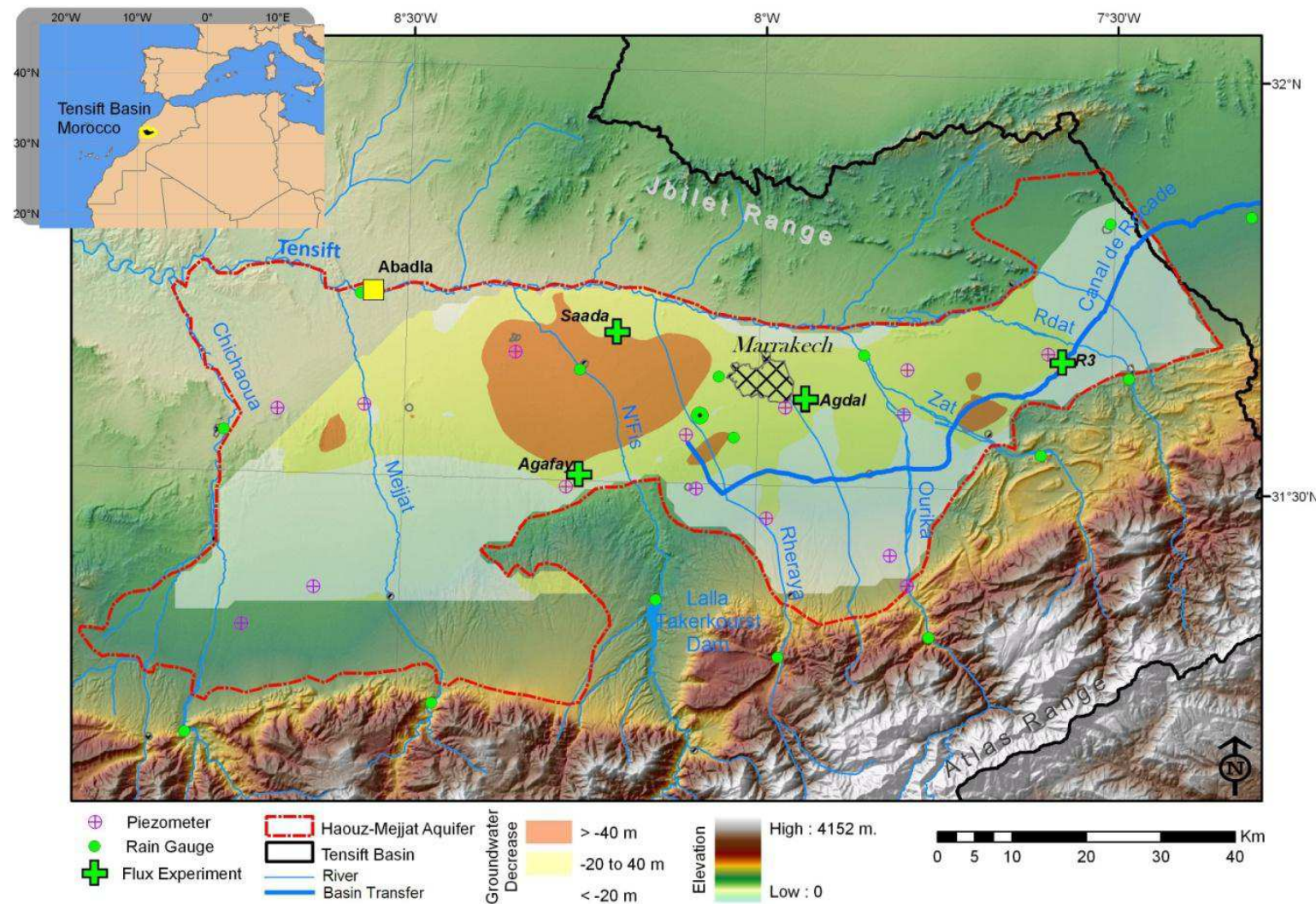

Fig 1) have been used. Rainfalls were compiled on a monthly time step and a simple Voronoï triangulation was applied. Spatial distribution of rain gauges is sparse and not fully optimal for spatial interpolation. In the case of the Mejjat area, almost devoid of information, a simple mean of the three nearest plain stations was applied discarding the piedmont rain gauge. Average monthly rainfalls

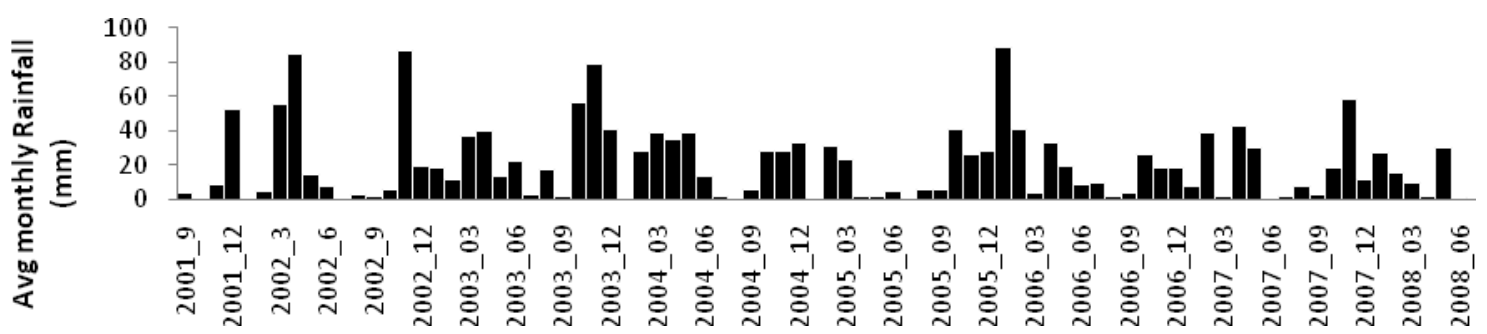

Fig. 2) are low and irregularly distributed from one year to another, largely influencing sowing dates and water demand in general. 
Fig. 2: Average monthly rainfall of the Haouz-Mejjat plain (2001-2008).

Finally, in situ ETs are used to validate the satellite estimates. During the Sudmed Project (Chehbouni, Escadafal, B., \& Al, 2008), several experimental flux measurements sites including Actual Evapotranspiration (ETa) have been installed over the Haouz Plain

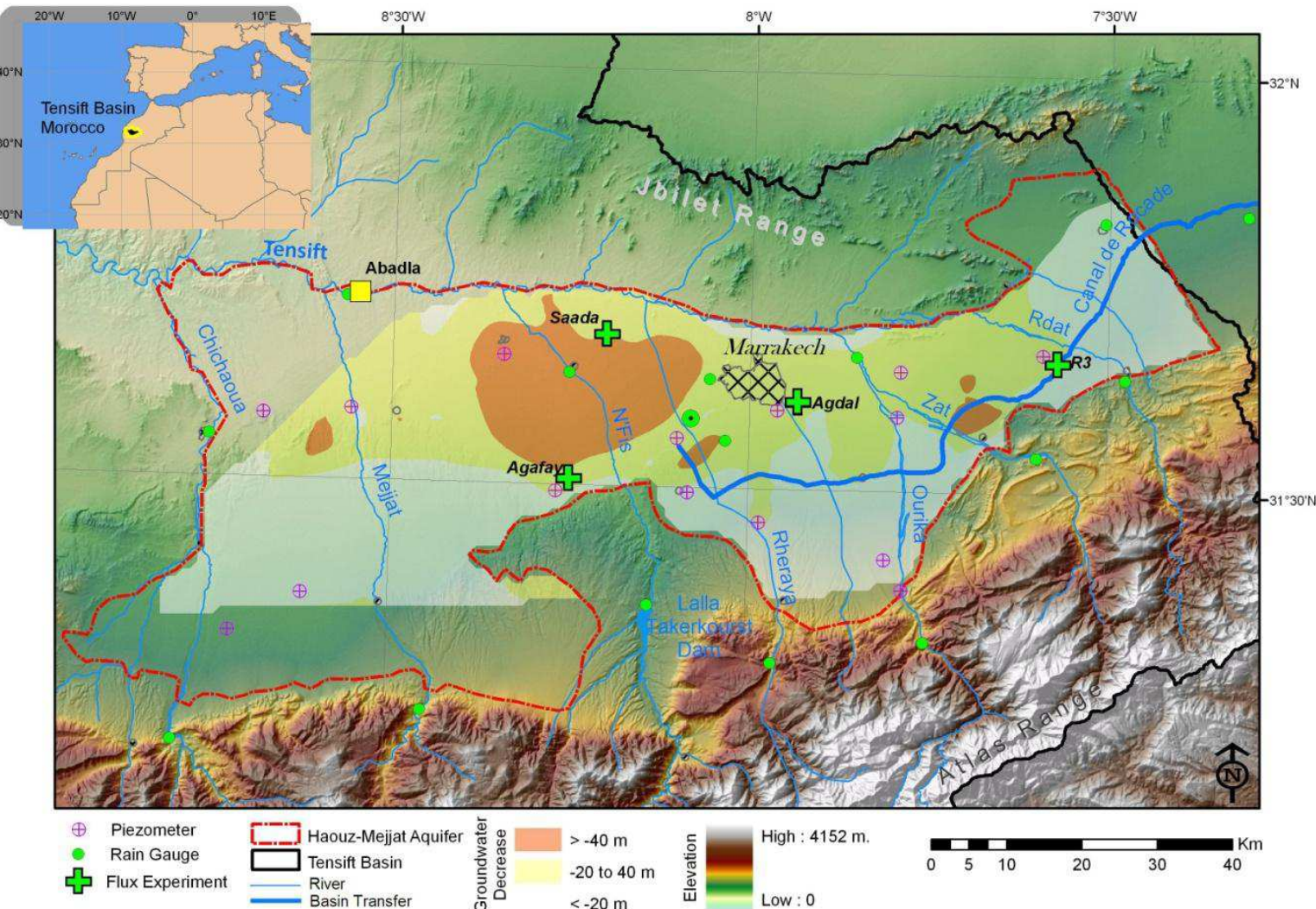

Fig 1). Also each test site has achieved specific goals; the measurement of actual ET (Eta) has been quite generic. An eddy covariance system, consisting of a 3D sonic anemometer (CSAT3, Campbell Scientific Ltd.) and an hygrometer (Li7500, Licor Inc. or KH20, Campbell Scientific Ltd.), was installed over the main crops of the region to provide continuous measurements of vertical fluxes of heat and water vapor. Detailed description may be found in (Er Raki et al. 2007; Ezzahar et al. 2007; Duchemin et al. 2006).

The eleven validation sites (Tab. 3) include measurements spread from 2002 to 2009 over the three dominating crops of the region. Olive groves have been followed on two sites: Sud Agdal is populated with 250 year old olive trees with a 60\% fraction cover and flood irrigated while Sidi Rahal is a modern (drip irrigation) and recent plantation (2005) which greatly evolved during the measurement period (2006-now). Citrus groves have been measured on three sites (Saada1, Saada2 and Agafay). The first and last ones are 
drip irrigated, with dense and regular spacing, while Saada2 is flood irrigated and is heterogeneously and irregularly spaced.

The wheat fields were measured during the 2002-03 and 2004 season on four different flood irrigated fields.

\subsection{Raw Remote Sensing observations}

The remote sensing observations are used for the computation of the FAO-56 crop coefficient method and the land use which are the two main inputs for the agricultural water demand estimate (see below)

All the treatments are based on the extensively used Normalized Difference of Vegetation Index (NDVI) time series. The medium resolution dataset is obtained from MODIS Terra, product MOD13Q1, version 005 (freely available on ftp://e4ft101u.ecs.nasa.gov). Global data is provided every 16 days at 250-meter spatial resolution as a gridded product. MODIS VI products rely on the level 2 daily surface reflectance products, which are corrected for molecular scattering, ozone absorption, and aerosols (Justice et al. 2002). The compositing methodology is fully developed in (Huete et al. 2002).

Preprocessing involves reading HDF original format, projection on the Moroccan Lambert Conical Conform grid, layer stacking of each NDVI date into a single multi-band image, and finally cropping on the study area. A High Resolution time series is used for calibration at the land survey scale and validation at a larger scale: Eight Landsat TM were acquired from November 2002 to May 2003 (7/11, 25/12, 26/01, 11/02, 27/02, 31/03, 16/04, 18/05). Each 30 meters spatial resolution scene received a geometrical and atmospheric correction (Simonneaux et al. 2007). Two field surveys were carried out this period, the first one, called here R3 survey was an exhaustive survey of a $24 \mathrm{~km}^{2}$ rectangle, $40 \mathrm{~km}$ east of Marrakech, the second is done along a path over the Tensift watershed.

\subsection{Land Use Classification and Evapotranspiration estimate}

In order to classify Land Cover, a simple threshold classification applied on the whole NDVI time serie mainly based on Simonneaux (2007) was chosen. Supposing that the vegetation index is not altered along time (which is verified on bare soil with a constant NDVI around 0.15, but difficult to assess in higher differences), this technique has the main advantage of being reproducible from one year to another. The process was then conceived in two stages. The first stage consisted in calibrating the three thresholds comparing high resolution Landsat TM from 2002-03 to land surveys. Although very satisfactory to distinguish between bare soils, annual crops and tree crop, this part of the study revealed that it is difficult to separate well developed fallows from under-developed annual crops (included irrigated crops). In fact, both of them may reach its maximum NDVI around 0.4. Unfortunately, the sparse temporal distribution of Landsat scenes could not give further detail about the seasonality of fallows compared to other annual crops (A delay in the initial development stage or harvest could not been studied because of the imagery average monthly time step). Calibration gave three thresholds $0.18,0.36,0.48$ to obtain 4 main classes: Bare soils or Fallows, Annual crops, Trees only, and a class which includes a mix between trees and annual crops.

The evapotranspiration estimates are derived from the extensively used FAO-56 approach driven by NDVI time series. The processing involves two steps with the SAMIR tool (Simonneaux et al. 2007):

- For each land use class, establish the relationship between the NDVI and Crop Coefficient (Kc) and the relationship between NDVI and Fraction Cover $(\mathrm{Fc})$. 
The relationships Fc-NDVI and Kc-NDVI are taken from the bibliography (Tab. 1). The water demand from bare soil or fallow is not estimated; in the budget those areas will consume the majority of rain. Trees on bare soil are assigned a constant $0.6 \mathrm{Kc}$. Mixed areas are assumed to have a linear relation to Fraction cover (Hua, Raupach, \& McVicar, 2001). As wheat is the dominant crop of the area, the relationships found by Er Raki et al. (2007) on the Haouz plain are used for the annual class.

The treatment for this late relation is specific. This is a Kcb-NDVI relation, so we used an arbitrary Evaporation Coefficient $\mathrm{Ke}=0.2$, which would be applied for non covered area (1-Fc). Fc is also prolonged at the same level for a maximum of 70 days after reaching maximum NDVI in order to reproduce the senescence stage when the VI goes down while the vegetation cover is maintained. Kc and Fc were finally linearly interpolated to a daily time step.

The final step (ETsat=Kc.ET0) is then straightforward, only paying attention to the different spatial resolution of both matrices with a linear resampling. Although satellite imagery was available for a longer period of time, calculation was only achieved for the 2001-2008 period.

\begin{tabular}{|c|c|c|c|}
\hline Class & Kc & $\mathrm{Fc}$ & Reference \\
\hline Annual & $\begin{array}{l}\mathrm{Kc}=\mathrm{Fc} .[1.64 . \mathrm{NDVI}- \\
0.2296]+[0.2 .(1-\mathrm{Fc})]\end{array}$ & $\begin{array}{l}\text { 1.18.NDVI - } \\
0.1652\end{array}$ & Derived from Er-Raki, 2007 \\
\hline Trees on bare soil & $\mathrm{Kc}=0.6$ & 1.50.NDVI - 0.225 & Hua et al, 2001 \\
\hline Mixed Tree/Annual & $\mathrm{Kc}=0.5303 . \mathrm{Fc}+0.2205$ & $\begin{array}{l}\text { 1.3188.NDVI + } \\
0.0133\end{array}$ & Darke et al, 1997 \\
\hline Bare soil or Fallows & $\mathrm{Kc}=0$ & $\mathrm{Fc}=0$ & \\
\hline
\end{tabular}

Tab. 1: Relations used for the calculation of Crop Coefficients

\subsection{Monthly water flows}

\subsubsection{Hydrometric network}

The hydrometric network is managed by the water basin agency. Flows coming from the Atlas range are monitored on the seven main atlasic watersheds covering an area of about $4800 \mathrm{~km}^{2}$. Streamflows are measured in unstable rock bed based on a scale. Interestingly enough, the beds are changing from time to time as important events occur. Thus, despite a monthly gauging frequency, rating curves are difficult to compute and measurements may encounter errors. The sole reference hydrological station is the one called Abadla, located between the N'Fis and the Assif el Mal confluence over the Tensift River.

River flows are characterized by a strong annual and interannual variability (Fig. 3.b) depending on the annual rainfall amount and snow accumulation. Over the year, the distribution is clearly bimodal (Fig. 3.a) as higher temperature prevent snow accumulation of the important raining events of autumn (Rdat, Zat, Ourika, Rheraya), whilst higher rates are observed in spring. 

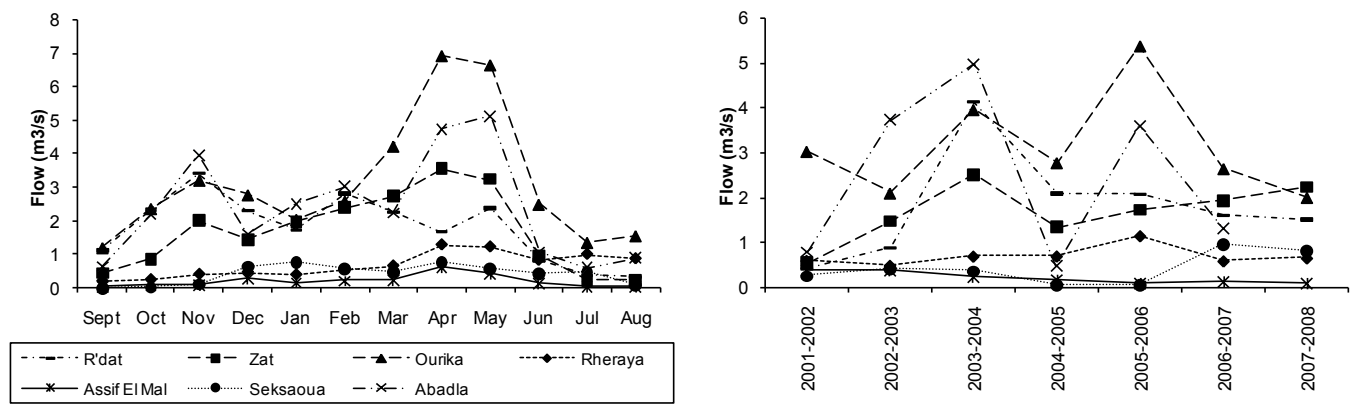

Fig. 3: Annual variability (left) and interannual variability (right) of the main Atlasic River flows

\subsubsection{Traditional irrigation, Dam management}

Data from several public institutions have been collected and aggregated to feed the DSS. Water volumes estimation concerns:

- The volumes derived into Traditional Irrigation sectors are monitored by ORMVAH except for the areas of Assif el Mal and Seksaoua. Derivation estimates were calculated for uncontrolled basins in reference to hydrologically similar context.

- Concerning dam management, the releases and their spatial assignments are compiled

- Urban pumping is monitored by ONEP, including the well field of the city of Marrakesh and other towns distributed around the area. Over the period 2001-2008, the volumes collected have decreased significantly, from $1410^{6} \mathrm{~m}^{3}$ in 2001 - to only about $6.510^{6} \mathrm{~m}^{3}$ in 2008 . The lower volumes of small cities are aggregated by planning units.

\subsubsection{Groundwater monitoring}

The Haouz-Mejjat aquifer is currently controlled by a battery of 34 piezometers, 23 of which are old, 4 are rehabilitated, 3 are newly dug out and 4 are equipped for continuous recording. Uncontrolled areas are located along the southern boundary and in the eastern part of the aquifer. Many piezometers have a short observation period and only ten of them cover the whole simulation period, including some shortcomings and the unmonitored years 2004 and 2005. In addition, several piezometers are not graded. To ensure a better spatial coverage, some piezometers with a short period of observation were added to complete the time series, totaling 21 calibration points.

\section{Assessment of input data and practical implementation}

\subsection{Validation of Land Use}

Cross validations of the classification based on the high resolution LANDSAT data set gave satisfactory although not exceptional results. The R3 survey is almost devoid of trees (7\%), and the cross validation for trees is obviously low (63\%). In the same area separation between annual crops and fallows/bare soil gave a 
quite acceptable 75\% score. Those scores are higher for trees in the whole region survey, but a bit lower for annual crops. (Tab. 2)

\begin{tabular}{|l|c|c|}
\hline Ground Truth & R3 survey & Tensift survey \\
\hline Annual crops & 0.73 & 0.65 \\
\hline Mixed Trees and Annual Crops & 0.63 & 0.76 \\
\hline Fallows or bare soil & 0.76 & 0.89 \\
\hline
\end{tabular}

Tab. 2: Cross validation of Land Use between Landsat and field survey (year 2002-03)

The second stage was to classify the 2002-03 MODIS time series and to compare it to the Landsat classification. A resampling of each entry at $270 \mathrm{~m}$ spatial resolution was fulfilled, and a cross-validation was carried out. The cross validation gave good results on annual crops and mixed trees (>80\% concordance) and not surprisingly, the tree alone class was almost not found on the MODIS classification (22\% concordance) due to the lower resolution and the small size of trees plots.

\subsection{Validation of agricultural water demand}

Although local measurements of actual evapotranspiration are hardly comparable to MODIS estimates due to significant scale differences, it gives a good idea of the error range (Fig. 4 and Tab. 3). The average yearly error is $-6.5 \%$. Three years out of 10 gave bad results $(\varepsilon>15 \%)$, three gave average results $(5 \%>\varepsilon>15 \%)$, four gave good results $(\varepsilon<5 \%)$. The worse result were obtained on the olive grove in $2006(-29 \%)$ and the wheat plot 130 in 2002 (-34\%) (Tab. 3). The bad result of the olive grove is explained by a wrong classification of the still young olive trees into annual crop. Block 130 is located next to a large bare soil area which resulted into lower NDVIs at the MODIS pixel scale. It is not really an error but a resolution issue between the representativeness of the in situ experiment and the imagery spatial resolution. An important underestimation $(15 \%)$ is also noticeable on Saada2 (orange) that may be explained by a well-developed under-storage. The cyclic overestimation over the tangerine grove of Agafay (15\%) could not be explicated.

The process that leads to ET estimates is prone to three major kinds of drawbacks. (1) ET0 ground stations may be inaccurate. It is a known fact that the maintenance of the reference grass is difficult in semi-arid areas (Allen et al. 1998) (2) classification mistakes may lead to huge errors, not only in the ET estimate as shown for Sidi Rahal in 2006, but also in the area involved in each class, (3) short period of water stress cannot be identified by this method as the greenness of the plant is not immediately influenced. 

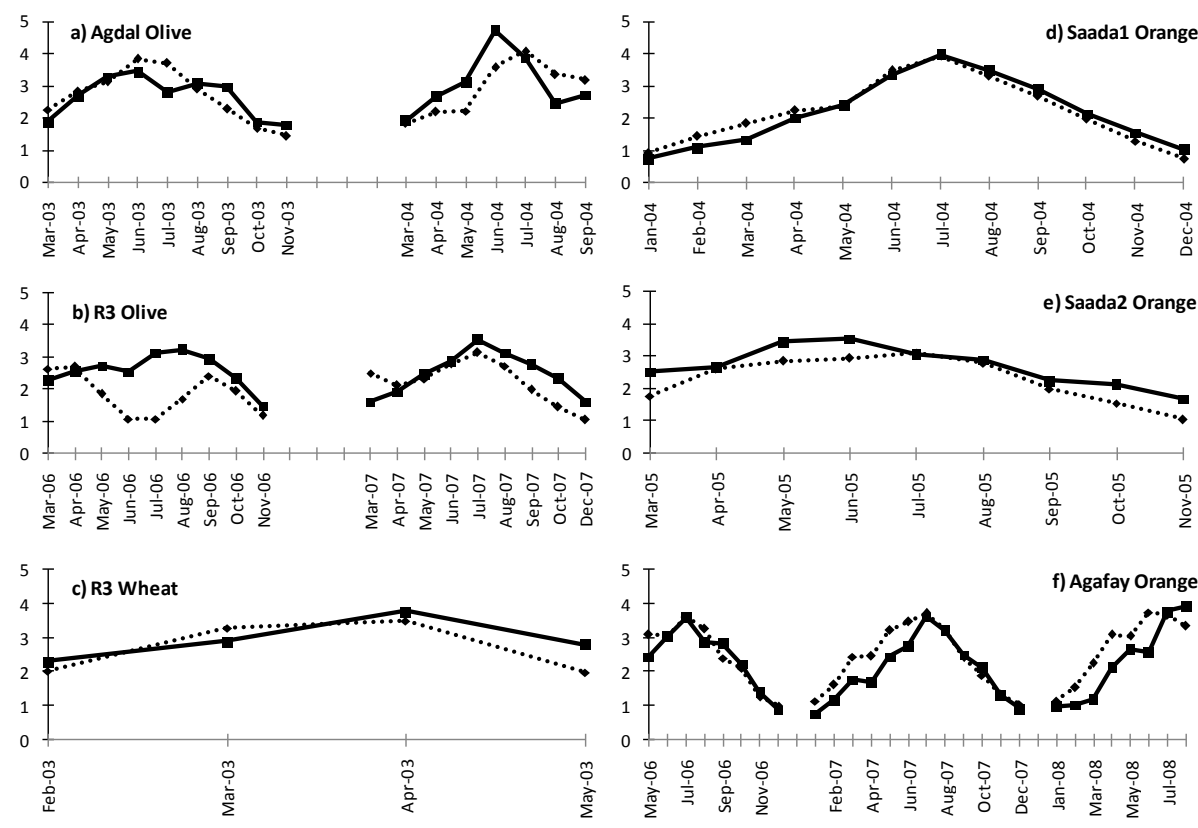

$\rightarrow$ ET measured $\quad$........ET Ealculated

Fig. 4: Comparison of average daily calculated and measured Evapotranspiration cumulated at Monthly steps in millimetres. The different crops are Olive (a and b), Wheat (c) and Citrus (d,e,f)

\begin{tabular}{|c|c|c|c|c|c|c|c|}
\hline Crop & Sites & Year & $\begin{array}{c}\text { ET } \\
\text { measured } \\
\text { total }(\mathbf{m m})\end{array}$ & $\begin{array}{l}\text { ET } \\
\text { calculated } \\
\text { total }(\mathbf{m m})\end{array}$ & $\begin{array}{c}\text { Total } \\
\text { Difference }\end{array}$ & RMSE & $\begin{array}{c}\% \\
\text { Error }\end{array}$ \\
\hline \multirow{4}{*}{ 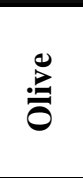 } & Agdal sud & 2003 & 728 & 736 & 8 & 0.44 & 1 \\
\hline & Agdal sud & 2004 & 655 & 625 & -30 & 0.71 & -5 \\
\hline & Sidi Rahal & 2006 & 712 & 507 & -204 & 1.06 & -29 \\
\hline & Sidi Rahal & 2007 & 683 & 615 & -68 & 0.57 & -10 \\
\hline \multirow{3}{*}{$\stackrel{0}{0}$} & Saada1 & 2004 & 796 & 803 & 7 & 0.25 & 1 \\
\hline & Saada 2 & 2005 & 737 & 630 & -108 & 0.48 & -15 \\
\hline & Agafay & 2007 & 742 & 854 & 112 & 0.52 & 15 \\
\hline \multirow{4}{*}{$\sum^{\bar{E}}$} & Bloc 123 & 2003 & 366 & 327 & -39 & 0.66 & -11 \\
\hline & Bloc 27 & 2003 & 228 & 269 & 41 & 0.54 & 18 \\
\hline & Bloc 130 & 2003 & 215 & 143 & -72 & 1.29 & -34 \\
\hline & Bloc 124 & 2004 & 276 & 271 & -6 & 0.58 & -2 \\
\hline
\end{tabular}

Tab. 3: Comparison of calculated and measured Evapotranspiration.

\subsection{Functional Zoning \& synthesis of $\mathrm{ET}_{\text {sat }}$}

The discretization of the study area into several functional areas determines the level of aggregation of evapotranspiration estimated by SAMIR and the definition of demand sites in WEAP. The purpose of zoning is to distinguish a limited number of areas, homogeneous in terms of water management, where surface water intakes are known.

The study area was first divided into five sub-basins. The second level of separation was realized according to the functioning described in part 2. Most of the areas were easily discriminated, but the task is particularly difficult in the case of the N'Fis area where modern and traditional networks cohabit and where surface water comes from the two sources. The other areas compass zones which in fact do not receive surface waters and also areas which can receive non-regulated water from wadi withdrawals during heavy floods.

As the objective is to define the areas over which a water balance is simulated, the third step is to discriminate inside the previously defined areas, rainfed from irrigated areas. The 9 Land Cover Maps (one 
classification map for each agricultural year between 2001 and 2009 based on available imagery) are

summed and a return frequency of each class is calculated. The final discrimination is obtained by a returning rule: the area is irrigated if 'tree' is present 6 out of the 9 years, or, if 6 out of 9 'annual' years occur on modern areas. The final zoning is a map of 49 functional areas (Fig. 5). The daily estimates of demand presented above are monthly aggregated for each zone. As water consumption by vegetation is out of phase from the monthly accounted water supply, an optimum 12 days delay was calculated in order to minimize pumping.

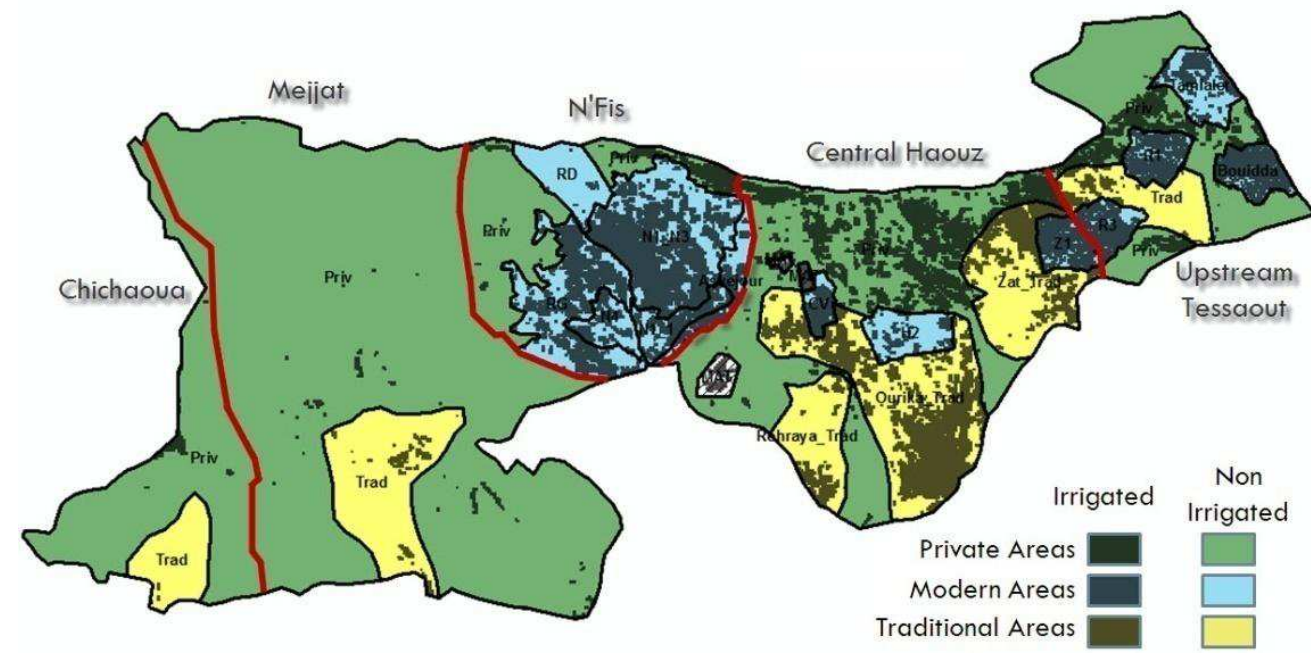

Fig. 5: Final zoning of the Haouz-Mejjat aquifer based on water resource and the frequency based dichotomy between irrigated and non-irrigated for the 2001-2009 period. Red lines separate the five planning units. Dark shades show irrigated areas, light shades show the non-irrigated areas. The three dark gray areas at the center of the map were not simulated because the origin of surface water could not be clearly identified.

\subsection{The WEAP implementation}

The five planning units are attached to a groundwater reservoir. The 'private' irrigated areas (the areas without superficial irrigation) pump directly into its corresponding reservoir, while the budget of the sectors is expressed through demand sites, allowing more flexibility in calculating the water balance.

Several semi-empirical assumptions based on bibliographic and local field studies are made on the general functioning of the area.

- Natural recharge is the groundwater recharge by direct infiltration of rainwater. Recharge is applied when the monthly rainfall exceeds a value greater than $20 \mathrm{~mm} /$ month. In irrigated areas where the soil is assumed to be wet, infiltration is facilitated (20\%), while only a small amount (5\%) may infiltrate in non irrigated areas. For the very dry areas of Mejjat and Chichaoua, where crusted soils are common, a decrease of 2 points is applied. (Bernet \& Prost 1975)

- The process of groundwater recharge in wadis is simulated in a simplified manner, using an infiltration coefficient on the flow volume left available after seguia water diversion. The infiltration coefficient is set to $25 \%$, which is a generally accepted value in previous studies of the 
region (Etude du Plan Directeur intégré des eaux du basin du Sebou, Bou Regreg, Oum Er Bia et Tensift, 1988)

Surface inputs are represented in WEAP in many forms. The main wadis of the study area are defined as 'River' objects and are assigned their measured streamflow. The Tensift River is depicted without upstream contribution but collecting inputs from the different wadis. The Canal de Rocade is defined as a "Diversion" with a known upstream contribution. Dam operations are not simulated and are only represented by unlimited reservoirs.

Linking and comparing requests and contributions is at the heart of any water resource management model. In WEAP, it is done through the GUI, drawing transmission links between the different objects and assigning priority levels for meeting demand and limitations on the delivered volumes. The non-consumed volumes are represented by "return links" enabling groundwater recharge from rivers or irrigation return to be simulated.

The demand and consumption rules used in our implementation are the following:

- Peff is the part of the rain that will be available to satisfy crop water demand. It is calculated as the difference between gross rainfall and the natural recharge coefficient.

- In private areas, the demand for irrigation water Dp is expressed as the difference between crop evapotranspiration ETc and Peff, multiplied by the surface area.

- In traditional sectors, Dt is the gross demand expressed as the difference between Etc and Peff (where the difference is positive), multiplied by the surface area and a factor Rt, which allows irrigation returns to be taken into account. In traditional areas, return flow is set to $20 \%$.

Consumption $\mathbf{C}$ (water lost to the system) is defined so that the return rate equals irrigation returns.

$$
D t=\operatorname{Max}\left[\left(E T c-P_{\text {eff }}\right) \times A r e a \times(1+R t)_{0} 0\right] \quad \text { eq. } 1
$$

$$
C t=D t /(1+R t) \quad \text { eq. } 2
$$

- The expression of the water demand of modern sectors Dm is built on the same basis as traditional sectors, but incorporates the management of irrigation surplus. The difference between Etc and Peff quantifies the surplus. A part of this surplus is used to recharge the groundwater as irrigation return when it is negative or lower than the supplied amount (Virr). The demand is at least equal to Virr. For the consumption expression, if demand exceeds the volume of surface water available, $\mathbf{C m}$ is defined for traditional sectors, but with a lower irrigation return flow $(\mathbf{R m}=15 \%)$, otherwise, a return flow associated to surplus irrigation is aggregated.

$$
\begin{gathered}
D_{m}=\operatorname{Max}\left[\left(E T c-P_{\text {eff }}\right) \times \text { Area } \times(1+R m), V_{i r y}\right] \\
C m=D_{m} /(1+R) \quad \text { if } D_{m}>\text { Peff }+ \text { Virr } \quad \text { eq. } 4 \\
C m=D_{m}-R \times\left[D_{m}-\operatorname{Max}\left[\left(E T c-P_{\text {eff }}\right) \times \text { Area } \times R_{v} 0\right]\right] \text { if } D_{m}<\text { Peff }+ \text { Virr }
\end{gathered}
$$

eq. 5 
Seguia demands are linked to its river in cascade. The first level matches the irrigated areas. The second level is considered as a possibly irrigated area that will benefit from overflows from the first level and extra diversion from heavy river floods. The first level is able to abstract water from groundwater, while it is forbidden for the second level. Finally after those withdrawals, a groundwater recharge may occur if a river flow remains (Fig. 6). The infiltration was set to a rate of $25 \%$ as stated earlier.

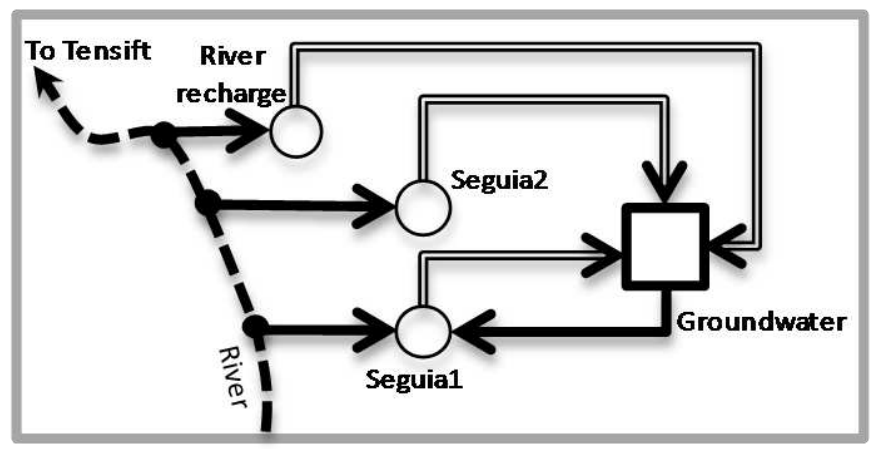

Fig. 6: Typical model for a traditional sector. Demand site objects are depicted by circles, while the groundwater stock is a square. Abstractions (from the river and groundwater) are identified by black arrows, return flows by double line arrows. Each object is linked to the MODFLOW model by an interface shapefile (Sieber and Purkey 2011).

Modern sectors are related to modern hydraulic structures (Canal de Rocade, dams) and groundwater. As with traditional sites, the linking rules simulate the groundwater withdrawals when surface water is not sufficient to meet the demand. Special cases are also implemented for the N'Fis area.

Other demand sites were created to express drinking water demand and the global demand of Marrakech Golf courses.

\subsection{The groundwater model coupling and calibration}

The main idea is to use MODFLOW (McDonald and Harbaugh 1988) to describe the spatial and temporal evolution of groundwater, using recharges and abstractions simulated in WEAP. The technical aspects of coupling are described in Sieber and Purkey (2011). The actual MODFLOW model comes from an extensive revision of a pre-existing annual model (Plan Directeur d'Aménagement Intégré des Ressources en Eau, 2002), and its adaptation to the monthly time step.

The groundwater model may be resumed this way:

○ The aquifer is mainly formed of siliciclastic deposits of Neogene and Quaternary age.

- Marls and clays of the Mio-Pliocene or Paleozoic shales are considered as the main substratum of the aquifer.

○ Initial hydraulic charges are derived from the piezometric campaign in 2001.

○ Boundary conditions are adopted as follows:

$\circ$ the southern boundary, representing the contact between the aquifer and the High Atlas, is simulated as constant head or no-flow boundary ; 
o the eastern boundary is of constant head in the south and no flow in the north;

o over their entire length, the Tensift river bordering the model in the north and Chichaoua river in the west, are a drain boundary.

Adjustment steps involved correction of the substratum, estimate of a range of values for the high-Atlas underflow firstly by using Darcy's law and secondly by addressing the water balance of High-Atlasic aquifers. For groundwater model calibration, the trial-and-error technique for adjustment of parameters was applied. The most important criteria used to check the calibrated model in terms of hydraulic heads are the mean error, the mean absolute error and root mean squared error (RMS). Hydraulic head measurements were obtained from an observation head network composed of 21 selected points.

After calibration, the obtained hydraulic conductivity map shows values ranging from $10^{-4}$ to $10^{-6} \mathrm{~ms}^{-1}$. The high permeabilities characterize the central part of the Haouz plain. The upstream part bordering High-Atlas Mountains has low permeability owing to the presence of deposits of low permeability at the distal end of the alluvial fans. The western Mejjat plain is also characterized by low permeabilities.

The storage coefficient varies between 2 to $8 \%$. The adopted zoning is fairly large because of poor knowledge of the variation of this parameter across the area.

Finally, recharge zones from High-Atlas has been identified from geological features (potentially permeable and impermeable formations) and available piezometric maps. An update is done firstly by using Darcy's law and secondly by addressing the water balance of High-Atlasic aquifers that overlook the Haouz-Mejjat plain. According to these calculations, an average inflow from 80 to $10010^{6} \mathrm{~m}^{3} /$ year should be adopted.

\section{Results and analysis}

\subsection{Validation}

\subsubsection{Downstream validation}

Figure 7 displays the observed and predicted monthly river flow at the Abadla gauging station from January 2002 to December 2008. Although no surface runoff is modeled, measured and simulated series fit fairly with a Nash-Sutcliffe coefficient of 0.52 and a correlation coefficient of 0.76 over the whole period. It is important to note that, as there is only one gauge station at the outlet, no particular calibration has been done for superficial flows. Indeed, infiltration coefficients for example, could have been easily calibrated to fit river flows. Downstream flows are the result of the several routings of the conceptual scheme and interaction with the groundwater model. Furthermore, changing river beds complicate river gauging as already underlined above, and flash floods, common at the mountain outlets, are rarely gauged. Major flood flows are then largely extrapolated. Finally, lack of infiltration and river withdrawal on the modeled Tensift River could also explain the general overshooting of the model. 


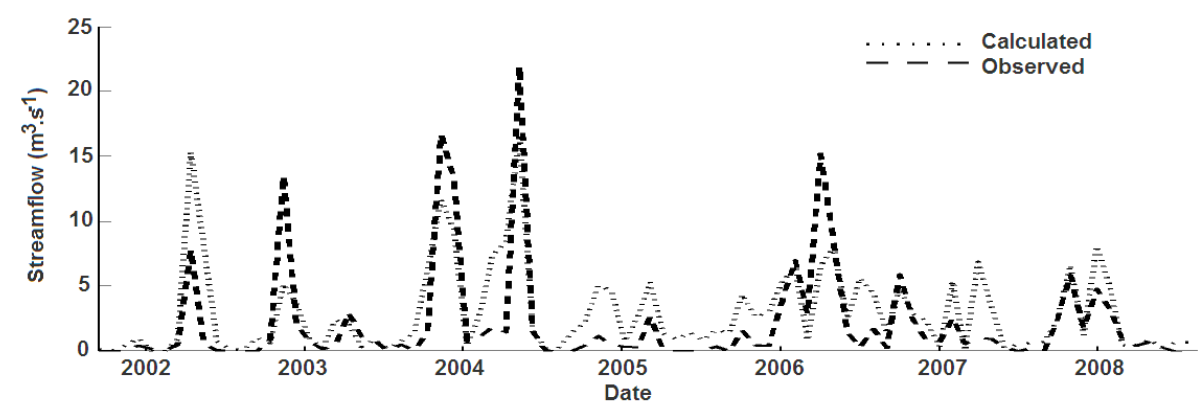

Fig. 7: Calculated and Observed streamflow at Abadla Station

\subsubsection{MODFLOW Water level (charge) prediction}

The calibration criteria included maintaining the mass balance requirements for the time steps (less than 1\% discrepancy) and the difference between the calculated and observed hydraulic heads within $\pm 5 \mathrm{~m}$. The qualitative criterion for the calibration was to create simulated hydraulic heads which had the same trends and the same magnitude of change as the observed hydraulic heads (Fig. 8). The comparison of mean error versus time step oscillate between -0.1 to 3 meters with an average of 1.6 meters. Leveling errors, insufficient knowledge about the aquifer and local uncertainties in assessing water budget terms, could lead locally to higher head difference. With regards to aquifer thickness and overall piezometric evolution, these differences are acceptable in most cases.

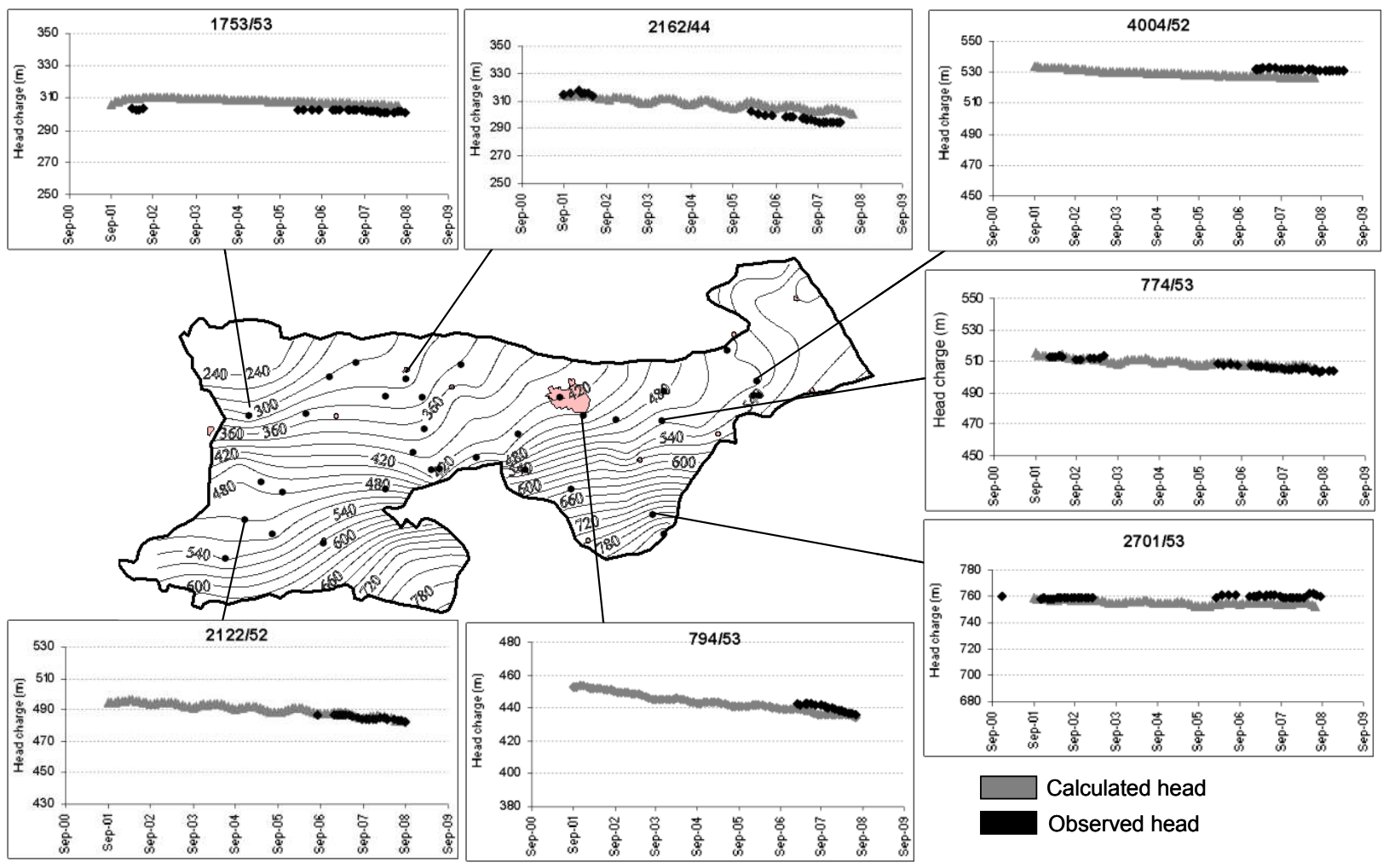

Fig. 8: Observed vs simulated heads of some observation points 


\subsection{Sensitivity analysis}

A simple sensitivity analysis was carried out in order to distinguish which parameters have the greatest influence in the coupled model output. The key parameters tested are the Return Flows (One for Modern areas, other for Traditional areas), Wadi Infiltration (percentage of non derived River flow returning to the aquifer), Minimum monthly Precipitation threshold for Infiltration and Effective precipitations (a coefficient for irrigated areas and another for non irrigated areas). The model sensibility to the different parameters is presented here as the evolution of the global aquifer stock related to the chosen value, and two reasonable extremes (Fig. 9).
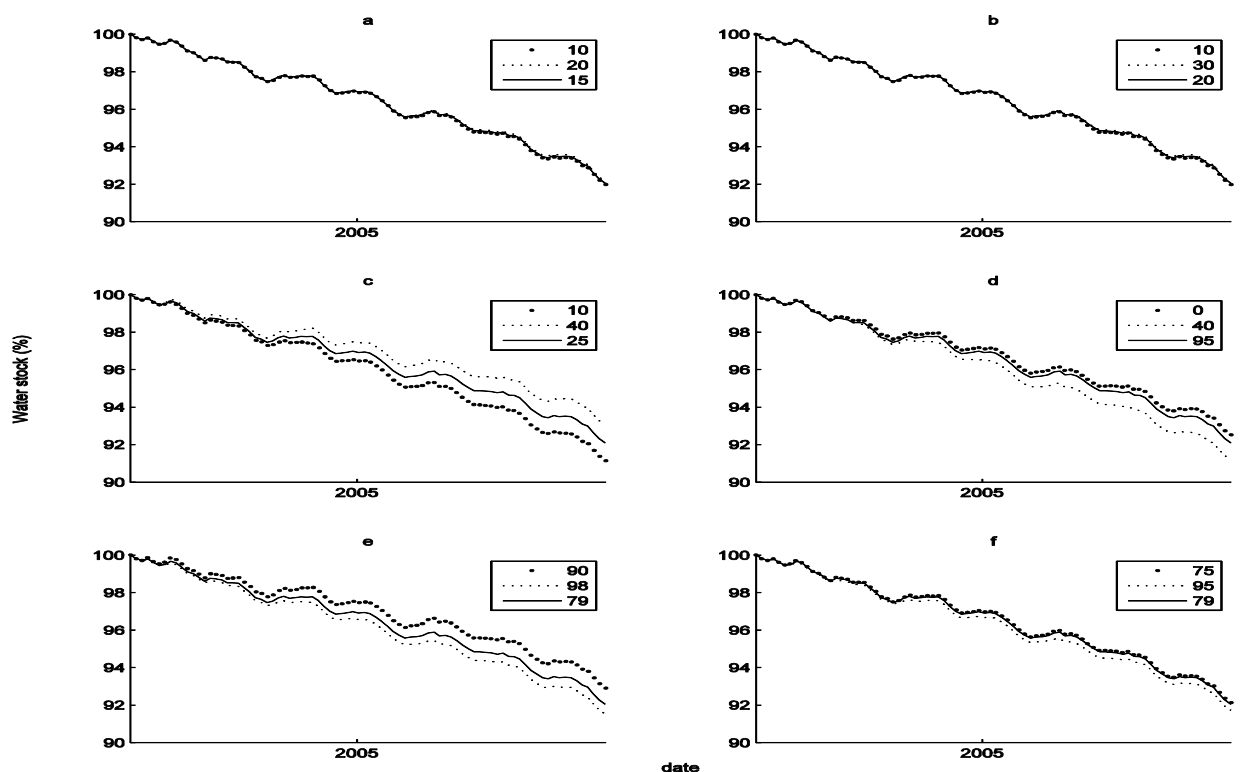

Fig. 9: Sensitivity analysis: Evolution of the total water stock over the period 2001-2008 for minimum, average and maximum value for a) Modern Irrigation Return Flow, b) Traditional Irrigation Return Flow, c) Wadi Infiltration d) Min Monthly Rainfall threshold for infiltration e) Efficient rainfall coeff in non-irrigated areas f) Efficient rainfall coeff in irrigated areas

The model appears slightly sensitive to the irrigation return rate both for modern and traditional sectors (Fig. $9 \mathrm{a}$ and b). It is easily explained by the modeling of the return rates (eq. 1 and 2). Indeed, those volumes are added to the estimated water demand, obtaining a gross demand. When groundwater is necessary to satisfy the demand, those volumes are extracted and returned to the aquifer in the same time step. On the one hand, those parameters play a role only when the demand is satisfied by surface water, on the other hand, they are mainly driven by the ETsat estimates. Sensitivity to the wadi infiltration coefficient is important (Fig. 9-c). The difference between extremes (10 to $40 \%)$ reaches $40010^{6} \mathrm{~m}^{3}(+/-20 \%)$ at the end of the simulation period. This coefficient is independent from all others as it only applies to underived wadi flows. Sensibility to the rainfall threshold for infiltration is naturally important (Fig. 9-d), as it applies to very large areas. The difference reaches $30010^{6} \mathrm{~m}^{3}$ at the end of the simulation with extreme settings of 0 to $40 \mathrm{~mm} / \mathrm{month}$. The last two parameters related to efficient rainfall in irrigated and non-irrigated areas have different impacts in the global aquifer storage. In non-irrigated areas, the difference between the two extremes (90 to $98 \%$ ) 
reaches $30010^{6} \mathrm{~m}^{3}$. The impact of this parameter is indirect. Indeed, it is the infiltration coefficient derived from efficient rainfall which explains the differences. In irrigated areas, efficient rainfall (Fig. 9-f) is less important. In fact, reducing efficient rain leads to an increase of water demand, generally satisfied by groundwater. Increase in extraction also increases recharge.

The analysis of those 6 parameters shows that further research should be made specifically on Infiltration in wadi beds and as natural recharge.

Finally, an analysis is carried out aiming to evaluate the impact of errors in evapotranspirations estimation. Figure 10 shows a central line without ET variation and the impact of $+/-10 \%$ and $+/-30 \%$ variation of evapotranspiration on the aquifer storage. As shown earlier, $10 \%$ is the expected error on evaporation estimates, meaning a variation of $90 \mathrm{Mm}^{3} / \mathrm{y}$. The extremes represent a variation of $+/-30 \%$. In fact, this is the maximum economy of water expected from conversion from gravity to drip irrigation, here calculated to $250 \mathrm{Mm}^{3} / \mathrm{y}$. Evapotranspiration is at the heart of water demands in irrigated areas. It exerts a major influence on the pumping estimates and the simulation of groundwater resources.

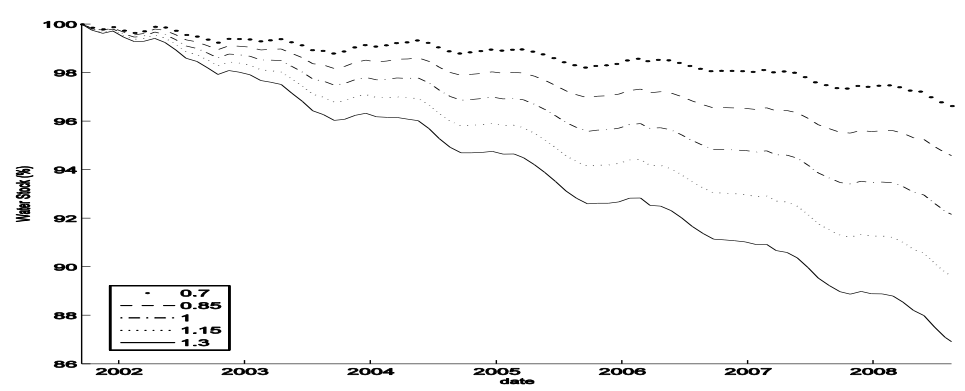

Fig. 10: Impact of Evapotranspiration on global groundwater storage on the 2001-2008 period, for average, $+/ 10 \%$ and $+/-30 \%$ variation.

\subsection{Confrontation of demand and supply}

Once the DSS is set up the functioning of the system may be analyzed on the object scale or at the planning unit scale. Fig. 11 shows the examples of the two most active areas in the Haouz-Mejjat aquifer. Both areas are contrasted in term of water inputs. N'Fis is very well supplied while Haouz central, a recent area of agricultural expansion, heavily relies on pumping. The demand (absolute and proportional) is stable above the period in both areas except during the dry year 2001. The influence of a dry year is less marked in the N'Fis than in the Haouz. It is easily explained by the preeminence of tree groves in N'Fis which are capable of remaining active during dry years thanks to a deep rooting system.

Seasonal cycle is also strongly marked due both to atmospheric demand and water supply from mountain flows and previous year dam storages. The wet 2006 winter caused a strong development of vegetation which was followed by an exceptionally hot and dry month of March. Consequently, the water demand of this month was particularly high. Although it cannot be proven, the actual water demand was probably lower than the one calculated. In fact, as stated earlier, our ET estimation method cannot assess water stress. 


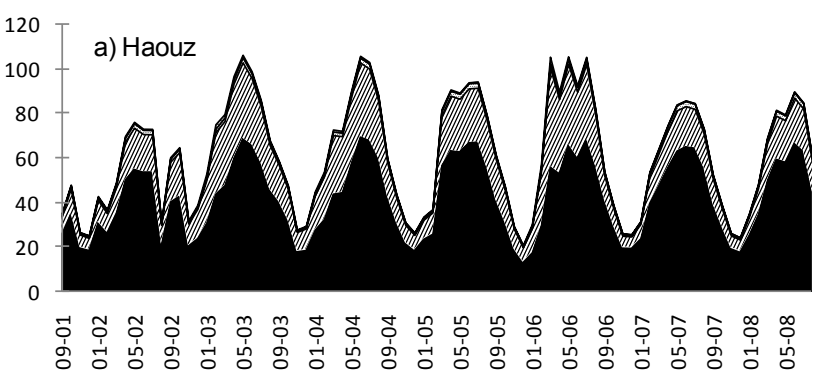

b) N'Fis

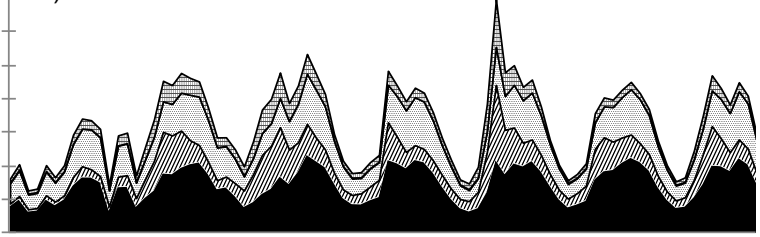

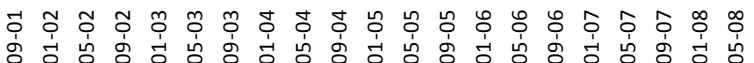

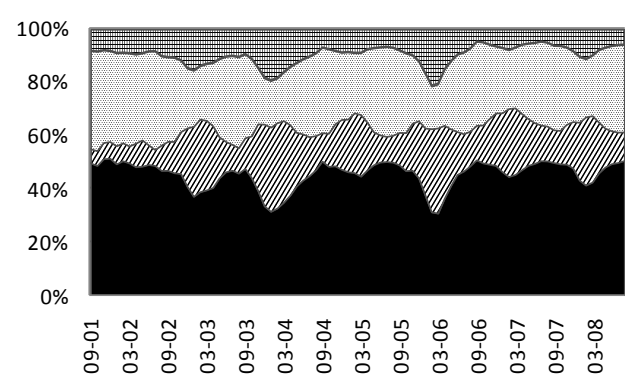

$100 \%$

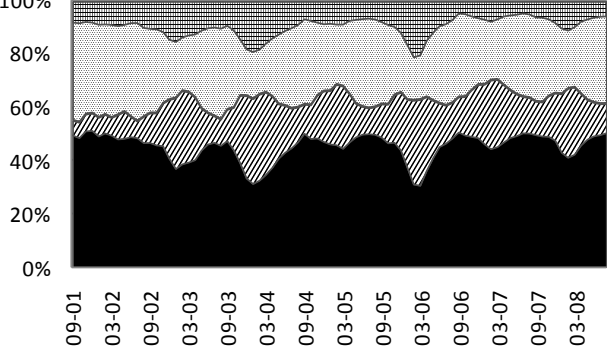

- Sup+Sub \%Superficialonly Rumpingonly 田Nolrrigation

Fig. 11: Gross Demand for Haouz Central in $10^{6} \mathrm{~m}^{3}$ at upper left and percentage at upper right. Gross demand for $\mathrm{N}$ 'fis in $10^{6} \mathrm{~m}^{3}$ at lower left and percentage at lower right

\subsection{Groundwater depletion}

53 of the 84 simulated months (2001-2008) show a deficit and the remaining are in excess. The surplus reaches a maximum of $3910^{6} \mathrm{~m}^{3}$ (Nov. 2003) with an average of $1510^{6} \mathrm{~m}^{3} / \mathrm{month}$. Average deficit is -30.5 $10^{6} \mathrm{~m}^{3}$ with a maximum of $-6310^{6} \mathrm{~m}^{3}$ (June 2008). The average monthly variation of the groundwater budget shows that the maximum deficits are observed from June to September (Fig. 12-a). The high agricultural demand during March and April are well balanced by rainfall and surface water contributions (Fig. 12-c). The annual deficit varies from -131 Mm3 for the year 2003-2004 to -279 Mm3 in 2007-2008. The cumulative budget deficit during the simulation period is about 1.1 billion $\mathrm{m}^{3}$. As confirmed by the piezometric network, this depletion was reflected by up to two meters a year of aquifer drop during the study period. 

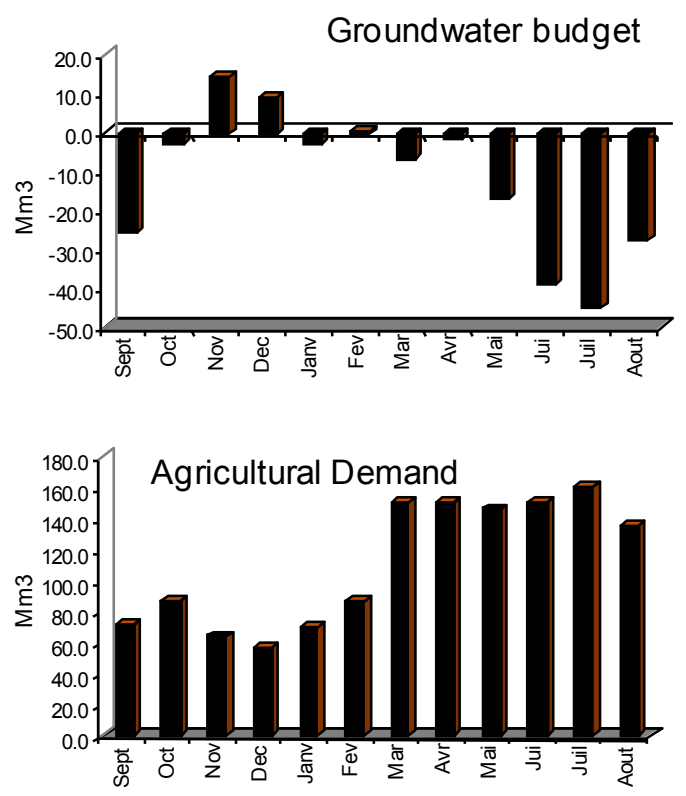
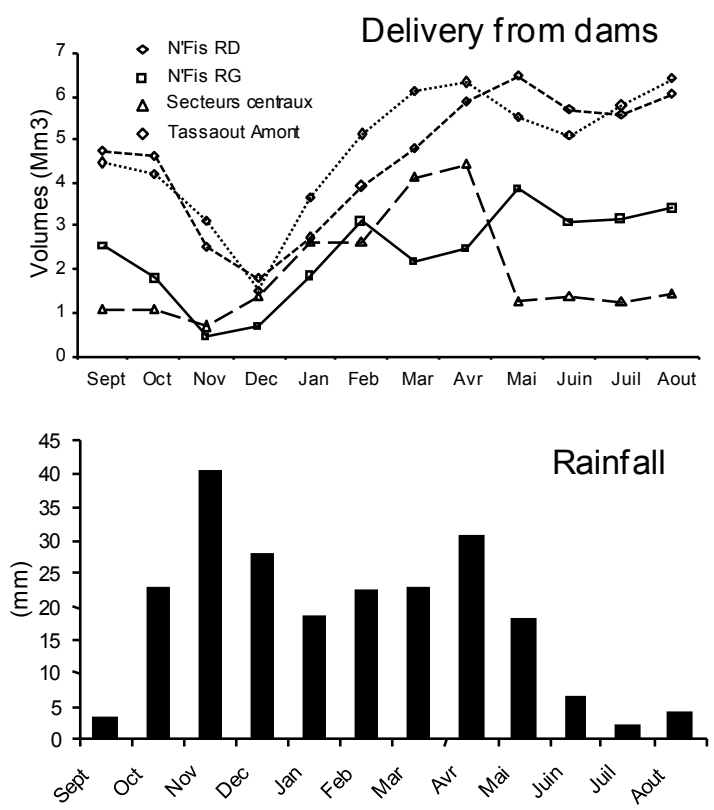

Fig. 12: Monthly calculated groundwater budget confronted to Agricultural demand, delivery from dams and Rainfall.

\subsection{Mitigation tracks}

The planning units are contrasted by their water supply and use, population and even climate. Chichaoua mainly depends on its eponymous wadi, and does not suffer from depletion. Mejjat is a large semi-desertic area with a large aquifer. Up to the 90s, only the outlets of the main wadis were exploited for traditional irrigation. Over the last 15 years, capitalist agricultural investors have progressively settled in the area, solely relying on groundwater. Those conditions are not sustainable. The N'Fis unit holds the wellfields of Marrakech and a mix of traditional and modern irrigation. It is an ancient irrigation sector with the best water surface resource of the study area. Nevertheless, agricultural demand, mainly orchards, is intensive and the groundwater stock is under pressure. The Central Haouz unit is a two-fold area: on the outskirts of the Atlas range, traditional irrigation diverts an important part of the river flows in compliance with provincial decrees of the beginning of the $\mathrm{XX}^{\text {th }}$, while the plain is occupied by extensive private areas which depend exclusively on groundwater.

The tracks for mitigation are different according to the planning units. Little can be done for the Mejjat unit, while for N'Fis, the generalization of localized irrigation is a solution actually under implementation thanks to the National Agriculture Plan. Drip irrigation installations are fully subsidized by the government, though it has to be taken into account that this reconversion is generally accompanied with a tightening of groves and an under-optimal use of the system, thus rarely reaching the $30 \%$ water economy expected. The sensitivity to ET driven above is a good indicator of the possible impact of drip reconversion. In the N'Fis and Haouz units, strengthening of the river recharge may also be an interesting way to prevent water from exiting the system as shown in Abadla outlet measurements and the sensitivity analysis. The increase of water offer is a more classical goal pursued by the regional authorities through the increment of basin transfers, or dam construction. Even though, the touristic atlasic valleys are not propitious to such alterations. Finally a more 
global track is the reinforcement of policies, including stopping the expansion of croplands and the quest of an Aquifer Contract between groundwater stakeholders.

\section{Conclusion}

A groundwater model has been set up on a $6000 \mathrm{~km} 2$ plain for a period of 8 years on a monthly time step. It heavily relies on freely available remote sensing time series for the determination of evapotranspiration. ET is put into a conceptual model which is used to allocate superficial water and determine net groundwater demand. The conceptual model is coupled to a groundwater model at each monthly time step. The final results are tangible both on superficial and subterranean references, although no calibration was made for surface flows due to the complexity of the model and lack of gauge stations. The model thus highlights (1) the need to intensify measurements particularly on river outlets, and (2) the need for further studies, particularly on recharge coefficients, substratum knowledge and mountainous underflows.

The solution is cost effective and the workflow is relatively simple making it reproducible for other semi-arid areas. Nevertheless, it should be accompanied with a good network of agroclimatologic ground stations and ground truth surveys for validation of land use.

Also the simplicity of the approach leaves certain flaws. The method for evapotranspiration estimate is quite bold and does not account for eventual water stress. A fully automatic hydric budget at the pixel level can be applied if a set of irrigation rules is spatialized. In the conceptual superficial model, physical processes are extremely simplified (eg infiltration coefficient) and should be deepened. Further improvement would also be to link water balance models of the Atlasic watersheds at the entrance to the plain, this way resulting in a fully-integrated model of the basin.

As for today, the whole constitutes a system for operational decision support, enabling the study of alternative strategies for planning, and facilitating communication with water users toward an Aquifer Contract.

\section{Acknowledgment}

This study was realized within the framework of the Joint International Laboratory TREMA, AGIRE project and ACSAD/BGR cooperation. The Tensift Basin Agency (Agence de Bassin Hydraulique du Tensift), which is a stakeholder in the two projects, played a key role in joining stakeholders. TREMA 'Remote sensing and water resources in semi-arid environment' involves the collaboration of CESBIO (Centre d'Etudes Spatiales de la Biosphère, Toulouse, France) the Cadi Ayyad University, Marrakech, Morocco, the Agriculture Office (Office de Mise en Valeur Agricole), thanks to the financial support of IRD (Institut de Recherche pour le Développement, France). AGIRE (Program to support the integrated management of water resources) involves the Ministry of Water and the Environment of the Kingdom of Morocco, the German International Cooperation (GIZ) and four Moroccan Basin Agencies. We are very grateful with each of these institutions for sharing their data and experience in this project. The Arab Center for the Studies of Arid Zones and Dry Lands (ACSAD) and the Federal Institute for Geosciences and Natural Resources, Germany 
(BGR) were the igniters of the WEAP-MODFLOW modeling through several workshops. Thanks to the Federal Institute for Geosciences and Natural Resources and Jack Sieber (SEI) for their technical support on WEAP. This study was also financially supported by Resamed project (Aquifer Recharge in the Mediterranean Area). We are grateful to the CNES (Centre National d'Etudes Spatiales, France) for its financial support during this work and for providing SPOT/LANDSAT images and facilitating the import of scientific equipment, the DMN (Direction de la Météorologie National, Morocco) for providing us with the outputs of the ALADIN model. Final thanks to Ian Timms for correcting the English version of the manuscript.

\section{Abbrevation list}

ET : Evapotranspiration

Eta : Actual Evapotranspiration

ET0 : Reference Evapotranspiration

$\mathrm{Fc}:$ Fraction Cover of vegetation

Kc : Crop Coefficient

Kcb : Basal Crop Coefficient

NDVI : Normalized Difference Vegetation Index

RS : Remote Sensing

VI : Vegetation Index

\section{References}

Abourida A (2008) Estimation des volumes d'eau pompés dans la nappe pour l'irrigation (Plaine du Haouz, Marrakech, Maroc). Comparaison d'une méthode statistique et d'une méthode basée sur l'utilisation de données de télédétection. Journal of Water, 21: 489-501.

Allen R, Pereira L, Raes D, Smith, M (1998) Guideline for Computing Crop Water Requirements (Vol. Irrigation and Drainage Paper $\left.n^{\circ} 56\right)$. FAO.

Al-Omari A., Al-Quraan S, Al-Salihi A., Abdulla F (2009) A Water Management Support System for Amman Zarqa Basin in Jordan. Water Resources Managegement , 23: 3165-3189, DOI:10.1007/s11269-0099428-z

Assaf H, Van Beek E, Borden C, Gijsbers P, Jolma A. (2008) Chapter Thirteen Generic Simulation Models for Facilitating Stakeholder Involvement in Water Resources Planning and Management: A Comparison, Evaluation, and Identification of Future Needs. In A. V. A.J. Jakeman, Environmental Modelling, Software and Decision Support. Elsevier.

Belghiti M (2008) L'agriculture irriguée au Maroc: Enjeux et marges de progrès. Revue HTE (139) 
Bernet, G., \& Prost, J. (1975) Le Haouz de Marrakech et le bassin du Mejjate. Ressources en Eau du Maroc, Tome 2. Rabat, Maroc: Notes et Mémoires du Service Géologique, nº 231.

Boudhar A., Duchemin B, Hanich L, Jarlan L, Chaponnière A., Maisongrande P, et al. (2010) Long-term analysis of snow-covered area in the Moroccan High-Atlas through remote sensing. International Journal of Applied Earth Observation and Geoinformation , 12: S109-S115, DOI:10.1016/j.jag.2009.09.008

Bzioui M (2004) Rapport national 2004 sur les ressources en eau au Maroc. UN Water Africa.

Castaño S, Sanz D, Gómez-Alday J (2010) Methodology for Quantifying Groundwater Abstractions for Agriculture via Remote Sensing and GIS. Water Resources Management, 24-4: 795-814, DOI:

$10.1007 / \mathrm{s} 11269-009-9473-7$

Chehbouni A., Escadafal R, et al (2008) An integrated modelling and remote sensing approach for hydrological study in arid and semi-arid regions: the SUDMED Programme. 2nd International Symposium on Recent Advances in Quantitative Remote Sensing. 29:478-423. Torrent, sp: Taylor \& Francis.

Courault D, Seguin B, Olioso A (2005) Review on estimation of evapotranspiration, from remote sensing data: From empirical to numerical modeling approaches. Irrigation and Drainage Systems (79-3-4), 223-249, DOI: $10.1007 / \mathrm{s} 10795-005-5186-0$

Debbi, F. (2004) Profil Environnemental de Marrakech, Agenda 21. Royaume du Maroc - PNUD.

Droubi, A (2008) Development and Application of a Decision Support System (DSS) fro Water Resources Management in Zabadani Basin (Syria) and Berrechid Basin (Morocco). Damascus.

Duchemin B, Hadria R, Er Raki S, Boulet G, Maisongrande P, Chehbouni A, Ezzahar J, Hoedjes J, Kharrou M, Khabba S, Mougenot B, Olioso A, Rodriguez J, Simonneaux V (2006) Monitoring wheat phenology and irrigation in Center of Morocco: on the use of relationship between evapotranspiration, crops coefficients, leaf area index and remotely-sensed vegetation indices. Agriculture Water Management, 79-1: 1-27, DOI:10.1016/j.agwat.2005.02.013

Er Raki S, Chehbouni A, Guemouria N, Duchemin B, Ezzahar J, Hadria R (2007) Combining FAO-56 model and ground-based remote sensing to estimate water consumptions of wheat crops in a semi-arid region. Agricultural Water Management (87-1), pp. 41-54, DOI:10.1016/j.agwat.2006.02.004

European Environment Agency (2006) The thematic accuracy of previous Corine land cover 2000. Assessment using LUCAS land use/cover area frame statistical survey. Retrieved 06 01, 2011, from http://reports.eea.europa.eu/technical_report_2006_7/en 
Ezzahar J, Chehbouni A, Hoedjes J, Er Raki A, Chehbouni Ah, Boulet G, Bonnefond J, De Bruin H (2007) The use of the scintillation technique for monitoring seasonal water consumption of olive orchards in a semi arid region, Agricultural Water Management, 89-3: 173-184, DOI: 10.1016/j.agwat.2006.12.015

FAO (2011) Aquastat Morocco. Retrieved from http://www.fao.org/nr/water/aquastat

FAO (2003). Review of World Water Resources by Country (Vol. Water Reports 23).

Höllermann B, Giertz S, Diekkrüger B (2010) Benin 2025-Balancing FutureWater Availability and Demand Using the WEAP 'Water Evaluation and Planning' System. Water Resource Management 24: 35913613, DOI 10.1007/s11269-010-9622-Z

Hua L., Raupach M, McVicar T (2001) Decomposition of Vegetation cover into woody and herbaceous components using AVHRR NDVI time series. CSIRO Land and Water, 35-01

Huete A, Didan K, Yin Y (2002) http://tbrs.arizona.edu/cdrom/VI_Intro/VI_MOD_VI_Prod.html. Retrieved from Terrestrial Biophysics and Remote Sensing Lab

Johannes M (2004) Modelling of the water balances in the Río Turbio aquifer, Mexico. Wageningen University.

Justice C, Townshend J, Vermote E, Masuoka E, Wolfe R, Saleous N, Roy D, Morisette J (2002) An overview of MODIS Land data processing and product status. Remote Sensing of Environment , 83-1-2:3-15, DOI:10.1016/S0034-4257(02)00084-6.

Kabbaj A, Zeryouhi I,Pointet T (1979) Alimentation en eau de la ville de Marrakech: projet à court, moyen et long terme. Influences sur la nappe. Effects of Urbanization and Industraialization on the Hydrological Regime and on Water Quality. Amsterdam: IAHS.

Margat J, Vallée D (1997) Démographie en Méditéranéee. Options Méditerranéenne. 31. CIHEAM.

Masson V, Champeaux J, Chauvin N, Meriguet C, Lacaze R (2003) A Global Database of Land Surface Parameters at 1-km Resolution in Meteorological and Climate Models. Journal of Climate , 169:1261-1282

McDonald M, Harbaugh A (1988) A modular three dimensional finite difference ground-water flow model. Techniques of Water-Resources Investigations, Book 6. U.S. Geological Survey.

McKinney, D. (2004) International survey of decision support systems for integrated water management. Bucharest, Romania: IRG PROJECT N 1673-000. 
Mobin-ud-Din A, Bastiaanssen W, Feddes R (2005) A new technique to estimate net groundwater use across large irrigated areas by combining remote sensing and water balance approaches, Hydrogeology Journal (13) Volume 13, Numbers 5-6, 653-664, DOI: 10.1007/s10040-004-0394-5

Mutiga J, Mavengano S, Zhongbo S, Woldai T, Becht R (2010) Water Allocation as a Planning Tool to Minimise Water Use Conflicts in the Upper Ewaso Ng'iro North Basin, Kenya. Water Resource Management 24-14:3939-3959, DOI: 10.1007/s11269-010-9641-9

Perera B, James B, Kularathna M (2005) Computer software tool REALM for sustainable water allocation and management. Journal of Environmental Management , 77-4:291-300,

DOI:10.1016/j.jenvman.2005.06.014

Rijsberman F. R. (2006) Water scarcity: Fact or fiction? Agricultural Water Management, 80-1-3:5-22, DOI:10.1016/j.agwat.2005.07.001

Sieber, J., Purkey, D. (2011). WEAP User Guide, http://www.weap21.org

Simonneaux V, Duchemin B, Chehbouni Ag, Cherkaoui M, Kharrou M (2007) SAMIR, a tool for evapotranspiration assesment using remote sensing. 2nd International Symposium on Recent Advances in Quantitative Remote Sensing. 29: 597-601, Torrent, sp: Taylor \& Francis.

Simonneaux V, Duchemin B, Helson D, Er-Raki S, Olioso A, Chehbouni Ag (2007) The use of highresolution image time series for crop classification and evapotranspiration estimate over an irrigated area in central Morocco. International Journal of Remote Sensing 29-1: 95-116, DOI: 10.1080/01431160701250390 